\title{
Mortality Reversal in Russia: The story so far
}

\author{
Vladimir M. Shkolnikov, Evgueni M. Andreev, \\ David A. Leon, Martin McKee, \\ France Meslé and Jacques Vallin
}

Care first of the Fatherland

Only then for yourself ...

From a popular song of the 1970s by A. Pakhmutova and N. Dobronravov

\section{Introduction}

commentator on population health, viewing the global situation as it was in
the early 1970s, could have been forgiven for concluding that the second
half of the twentieth century was unfolding as an overwhelming success. Although the world had, relatively recently, experienced a global conflict that had claimed many million lives prematurely, there was much to be optimistic about. Advances in technology were changing many lives for the better. In the area of health care, new drugs, technologies, and ideas were transforming the ability to prevent and treat disease. Many of the common infectious diseases that had taken children from their families were being vanquished and one, smallpox, was on the brink of eradication. Almost everywhere, life expectancy was increasing, in some places faster than at any time in recorded history. Indeed, many commentators were predicting, with confidence, sustained improvements, with the UN Population Division assuming that countries where life expectancy at birth was still under 62 years would experience a gain of 2.5 years in each period of five calendar years, after which the gain would decrease to about two years.' They had grounds for confidence as, until then, mortality trends in industrialized countries, as well as in

1 United Nations, World population prospects as assessed in 1980 (New York, United Nations, 1981), p 3. 
Asia, Latin America and Africa, had been remarkably resilient to major events outside wartime ${ }^{2}$, even including the Great Depression of 1929-33.

Yet thirty years later it is clear that this optimism was misplaced. It is true that, in most of the world, people are healthier than ever before. Yet in a few places the earlier gains are being reversed. ${ }^{3}$ The two greatest examples are sub-Saharan Africa, where infection with HIV has wreaked a horrendous toll, and the countries of the former Soviet Union, where the health gains of the post-war period have been reversed.

This chapter addresses the second of these examples, and in particular the largest successor state of the USSR, the Russian Federation. The experience of Russia during the last three decades represents the most long-standing and welldocumented case of mortality reversal, an exception from the global convergence towards a low-mortality regime. Russia and its neighbours in the then USSR, as well as the Soviet satellite states in Eastern Europe (until the 1990s) show how socio-economic, socio-psychological and socio-cultural circumstances can lead to sustained increases in mortality.

The inability of the USSR to improve the health of its population since the mid1960s was especially surprising in view of its earlier achievements. The communist system had placed a high priority on universal access to albeit basic health care, with a particular emphasis on prevention. In the post-war period it moved quickly to reduce the toll from vaccine preventable diseases. It established primary care facilities throughout a vast, and extremely dispersed, geographical area, using a model that became an inspiration for many other countries following the Alma-Ata conference in 1978. These achievements appeared sustainable; after all, this was the first country to place a satellite, and subsequently a manned spacecraft, in space. During the 1950s, the Soviet economy grew faster than that of any other European country and twofold faster than that of the other superpower, the United States. ${ }^{4}$ In the 1950s the Soviet health care strategy leaded to a great success in fight with infectious disease, rapid reduction of infant mortality and increase in life expectancy. ${ }^{5}$ Yet there were signs that all was not well as, in the mid-1960s, even as

2 P. Demeny, 'Investment allocation and population growth', Demography, 2 (1965), 203-232.

3 G. Caselli, F. Meslé, J. Vallin, 'Epidemiologic transition theory reversals', Genus, 58(1) (2002), 9-52; AJ McMichael, M. McKee, V. Shkolnikov, V. Valkonen, 'Mortality trends and setbacks: global convergence or divergence?', Lancet, 363 (2004), 1155-9.

4 R. Skidelsy, The Road from Serfdom: The Economic and Political Consequences of the End of Communism (New York, Allen Lane, 1995).

5 F. Meslé, J. Vallin, V. Shkolnikov, 'Reversal of mortality decline: the case of contemporary Russia', World Health Stat Q, 51 (2000), 191-206; F. Meslé, J. Vallin, V. Hertrich, E. M. Andreev, V. M. Shkolnikov, 'Causes of death in Russia: assessing trends since the 1950s', in 
the economy continued to grow (although at somewhat slower pace than it did in the 1950s), the upward trajectory in life expectancy came to a halt. In retrospect the deterioration in health can be seen as the first sign of the crisis facing the Soviet system, providing a warning that preceded that of any of the conventional macroeconomic indicators. Over the following twenty years, mortality continued to increase steadily, interrupted only by a short-lived improvement in 1985-1987, coinciding with Mikhail Gorbachev's wide-ranging anti-alcohol campaign. ${ }^{6}$ In the early 1990s deterioration resumed. During the 1990s mortality was predominantly increasing and Russia entered the $21^{\text {st }}$ century with an extremely low life expectancy for an industrialized country: 59 years for men and 72 years for women in 2002.

In summary, therefore, the experience of Russia is in stark contrast with that of many other countries, with the exception, until the early 1990s, of the countries of central and eastern Europe. This has meant that, while in the 1970s, the life expectancy gap between Russia and western countries was about 2-3 years for males and less than one year for females, it has now risen to 15-17 years for males and 7-8 years for females. The recent gains in Czech Republic, Hungary, Poland, Slovakia, and Slovenia have led to the emergence of a new mortality gap in Europe, between Russia and its former Central and Eastern European satellites.

In spite of numerous demographic, epidemiological and public health studies, we still do not fully understand forces behind both chronic health crisis since the mid1960 s and its more acute phase in the 1990s. It is fundamentally important to understand why Soviet society began to fail in the fight with emerging chronic and man-made diseases at the very moment of its maximum economic and military power and what factors were fuelling this process in a way that has had such prolonged effects. It is even more important to understand why now, in an era of new opportunities associated with the market economy, Russia remains so different from countries of Eastern Europe, continuing to fail in the struggle to reduce premature death.

Although many pieces of the jigsaw remain unknown, what is known deserves greater attention. This paper summarizes those studies that we have conducted during the last 15 years as well as drawing on other relevant work. The study documents the mortality reversal in Russia in a systematic way. It begins by examining the principal trends in aggregate indicators of mortality and health since 1970, decomposing them by time period, sex, age, major causes of death and

Population of Central and Eastern Europe. Challenges and opportunities, Ed by Irena E. Kotowska and Janina Jozwiak (Statistical Publishing Establishment, Warsaw, 2003), pp. 389-414.

6 S. White, Russia goes dry (Cambridge, Cambridge University Press, 1995).

7 F. Meslé, 'Mortality in Central and Eastern Europe: long-term trends and recent upturns', Demographic Research, 2004, Special Collection 2, Article 3. www.demographicresearch.org. 
population groups. The second part reviews current explanations for the health crisis in Russia, looking at their strengths and weaknesses. The concluding summary synthesises this evidence.

\section{Trends and Patterns of Mortality and Health Expectancy}

\section{Trends in Life Expectancy}

Figure 1 shows life expectancy at birth for men and women since 1970 in Russia and several comparator countries. Male life expectancy in Russia in 1965 was only 1 to 3 years lower than that in Japan, the USA, and Finland. From 1965 to 1984, Russia experienced a steady long-term decline in male life expectancy. This decline was followed by a series of acute fluctuations. First, there was a sudden increase in life expectancy from 1985 to 1987, followed by an equally rapid decline, which accelerated after 1991, reversing briefly between 1994 and 1998 before continuing its downward trajectory. Many associate the sudden improvement in the second half of the 1980s with Mikhail Gorbachev's anti-alcohol campaign launched in May $1985 .^{8}$ The sharp mortality increase in the early 1990 s coincided with a return to high alcohol consumption and with political and economic collapse of the Soviet state socialist system, followed by an unexpected and massive transformation of the Russian society. ' In 1995-98 the situation seemingly stabilized, but following the economic crisis of 1998 mortality has continued to increase. Four decades after its upward course was arrested, life expectancy at birth for men has reached 59 years. This is a unique value for an industrialized country in the beginning of the $21^{\text {st }}$ century.

8 F. Meslé, VM. Shkolnikov, J. Vallin, 'Brusque montée des morts violentes en Russie', Population, 3 (1994), 780-790; White, (1995); AV. Nemtsov, 'Alcohol-related human losses in Russia in the 1980s and 1990s', Addiction, 97 (2002), 1413-1425.

9 A. Avdeev, A. Blum, S. Zakharov, E. Andreev, 'The reactions of a heterogeneous population to pertubation. An interpretative model of mortality trends in Russia', Population: An English Selection, 10(2) (1998), 267-302; D. A. Leon, L. Chenet, V. Shkolnikov, S. Zakharov et al., 'Huge variation in Russian mortality rates 1984-1994. Artefact, alcohol or what?', Lancet, 350 (1997), 383-388; V. Shkolnikov, D. Leon, S. Adamets, E. Andreev, A. Deev, 'Educational level and adult mortality in Russia: an analysis of routine data 1979 to 1994', Soc Sci Med, 47 (1998), 357-369; V. Shkolnikov, G. A. Cornia, 'Population crisis and rising mortality in transitional Russia', in The transition's mortality crisis, eds. Cornia G. A., Paniccià R. (Oxford, Oxford University Press, 2000). 
Figure 1. Trends in life expectancy at birth since 1970 in Russia, Finland, Japan, Hungary, Lithuania, and the USA.
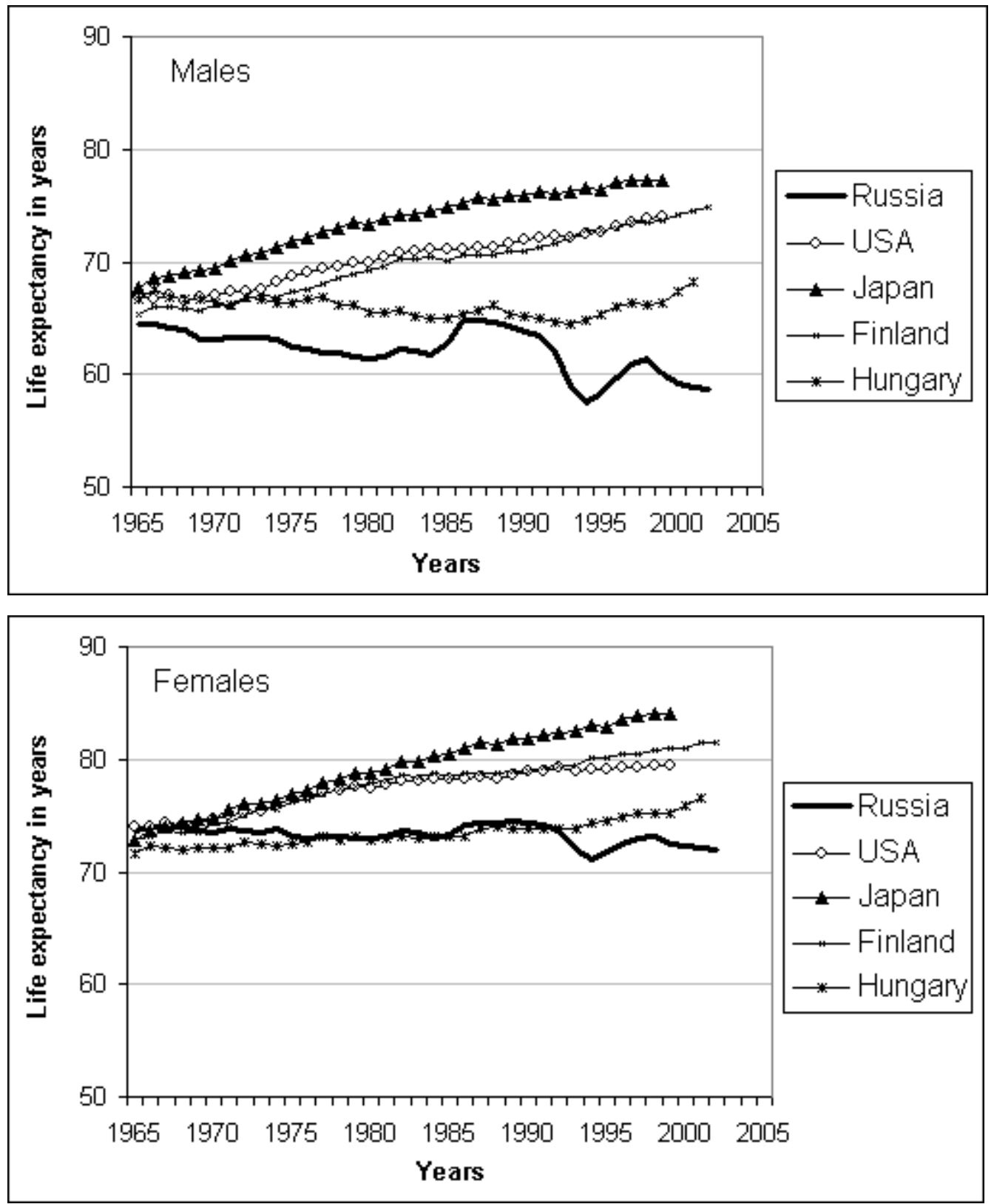

Source: Human Mortality Database, 2004.

The trend in life expectancy among women was quite similar to that of men. However, the pace of change was significantly more gradual. ${ }^{10}$ Before the 1990 s the situation was essentially one of stagnation rather than deterioration. In 2002 life expectancy for women was 72 years, producing one of the widest gender gaps ever recorded anywhere, at 13 years.

10 F. Meslé, J. Vallin, 'Évolution et variations géographiques de la surmortalité masculine Du paradoxe français à la logique russe', Population, 53(4-5) (1998), 1079-1102. 
The comparator countries each provide important contrasts. Japan is a late beginner in the epidemiological transition. In the 1950s, life expectancy at birth had been almost identical with that in Russia. Yet by the end of the twentieth century its position was the highest in the world due to a continuous and rapid progress in reduction of mortality from infectious diseases in the 1950s-60s and cardiovascular diseases in the 1970s-1990s. Finland was late to enter the major reduction of the cardiovascular mortality. This country started in 1965 from relatively low values of life expectancy at birth. Yet, unlike Russia, it maintained steady progress during the 1970s-1990s. The other superpower, the USA, also maintained steady progress in spite of relatively high levels of mortality from some causes of death such as cardiovascular disease, violence and HIV/AIDS, with the African-American population especially badly affected. ${ }^{11}$ The increase in life expectancy in the USA was continuous, but somewhat slower than either in Finland or in Japan. In Hungary, as in Russia, life expectancy was decreasing or stagnating in the 1970s and 1980 s, but by the early 1990s it embarked upon what can now be seen to be a sustained upward trend. Finally, Lithuania, a country of the former Soviet Union and a new member of the EU, has always had a slightly higher life expectancy than Russia. ${ }^{12}$ It experienced exactly the same steady deterioration in the 1970s and the same mortality fluctuations between the mid-1980s and the early-1990s. However, after a sharp mortality increase in 1991-93 it has experienced a decline in mortality and now seems to be departing from the Soviet mortality pattern.

\section{Age Patterns of Mortality}

Figure 2 is a result of regression analysis of log-mortality rates on time periods for six age groups: $0-14,15-34,35-49,50-64,65-74$, and 75+. It makes it possible to compare proportional changes in mortality rates at different ages in Russia with those in Eastern Europe (represented by Bulgaria, Czech Republic, and Hungary) and in the West (represented 12 countries of Western Europe plus Canada, Japan, and the USA). At all ages there is a clear contrast between Russia and Eastern Europe on one hand and other developed countries on the other. At age 0-14 mortality is decreasing everywhere, but its decrease in Russia is slower than that in Eastern Europe and much slower than that in the West.

11 K. D. Kochanek, J. D. Maurer, H. M. Rosenberg, 'Why did black life expectancy decline from 1984 through 1989 in the United States?', Am J Public Health, 84 (1994), 938-44.

12 Meslé, (2004). 
Figure 2. Effects of 5-year calendar periods on logged death rates for six age groups in Russia, Eastern Europe and the West for men and women.

Males
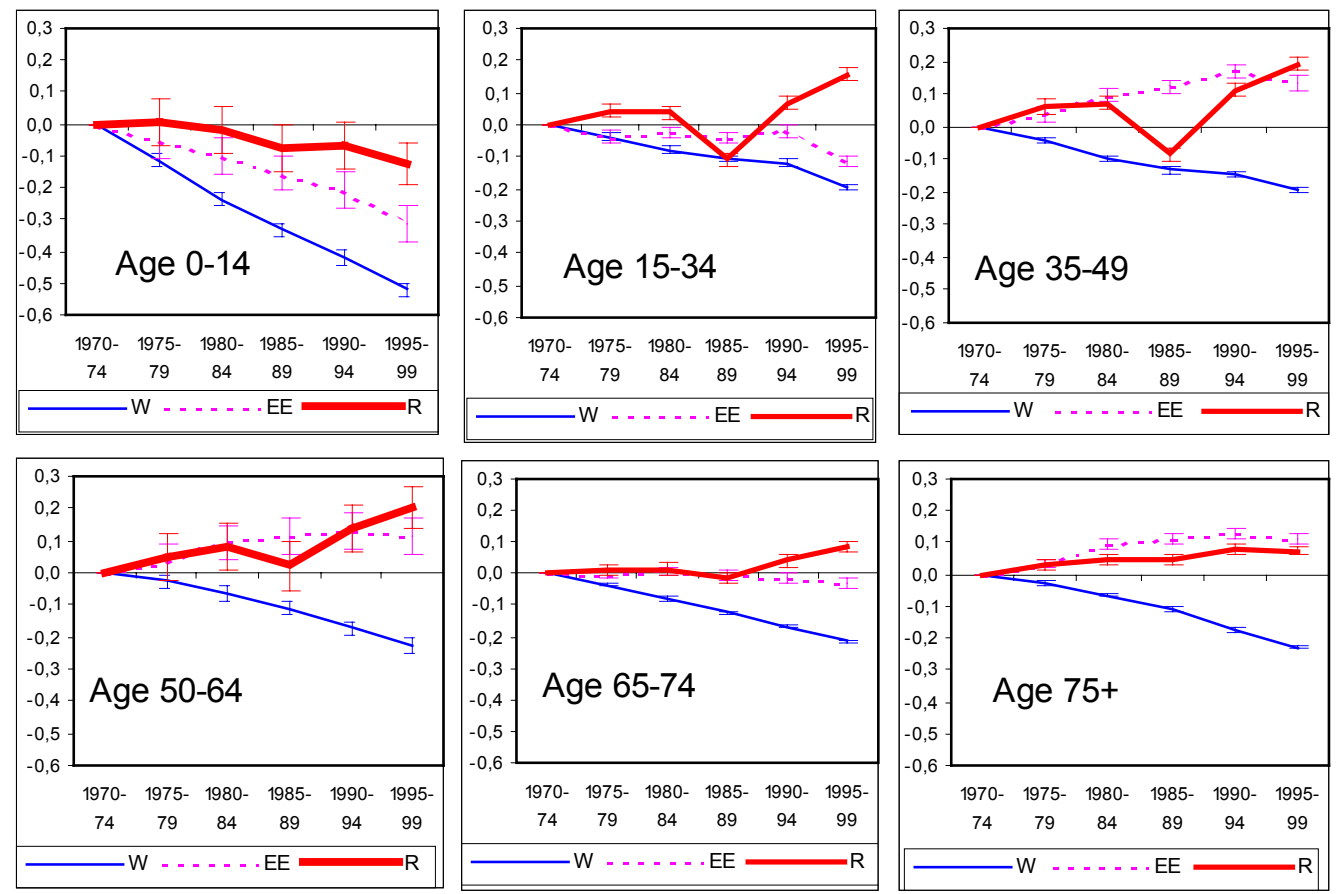

Females
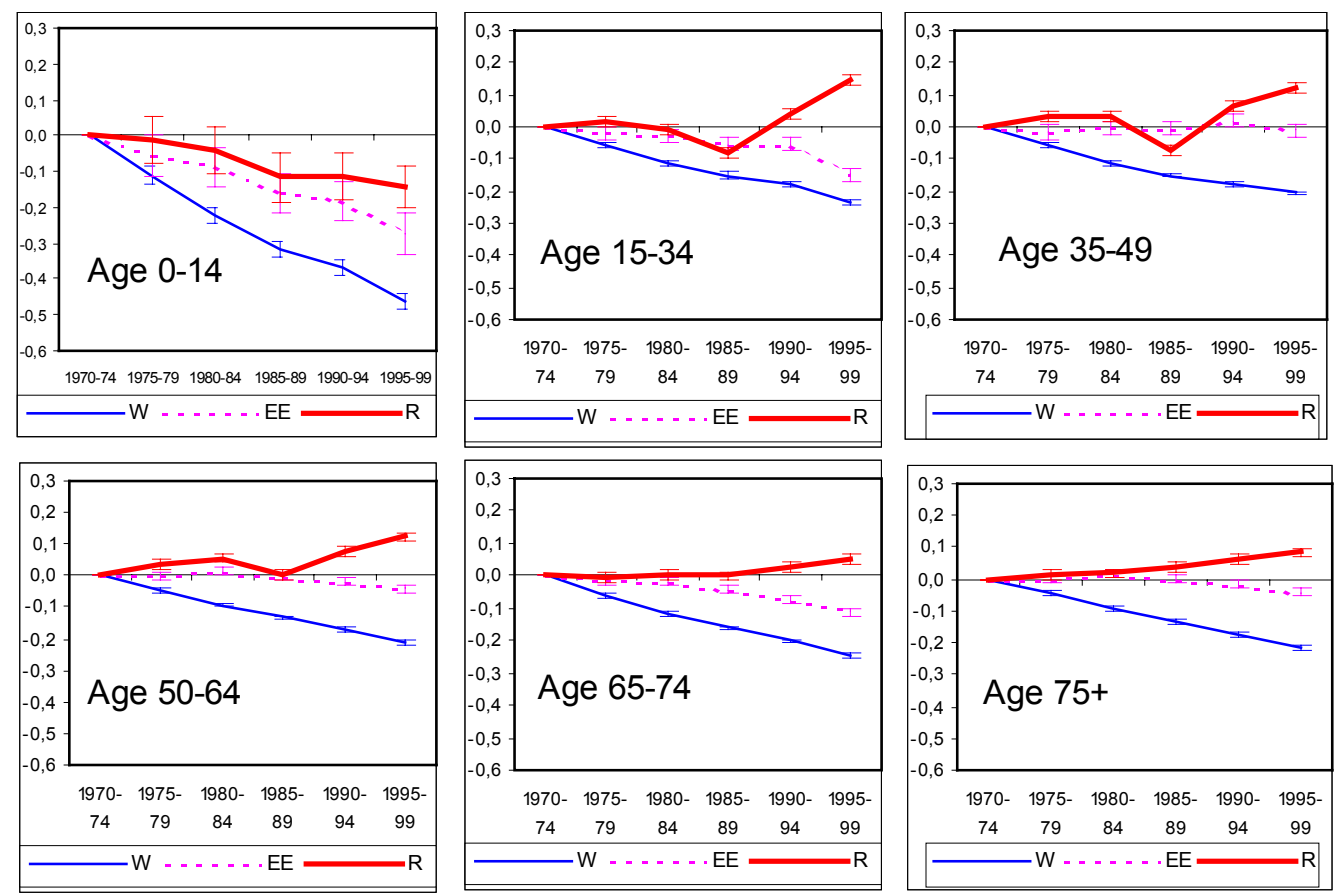

Notes: Coefficient of OLS regressions linking looged death rates for all country-year-age combinations with 5-year calendar periods. "Eastern Europé" includes Bulgaria, Hungary, and Czech Republic. "West" includes Austria, Canada, Denmark, England and Wales, Finland, France, Italy, Japan, the Netherlands, Norway, Spain, Sweden, Switzerland, the USA, and West Germany.

Source: Human Mortality Database, 2004. 
Between 1970-74 and 1980-84 Russian men experienced mortality increases at young adult and middle ages, while their Eastern European counterparts experienced mortality increases only at middle ages. Russian and Eastern European men aged 65-74 experienced mortality stagnation and some mortality increase at ages $75+$ between $1970-74^{13}$ and 1980-84. In 1985-89 mortality among Russian men dropped substantially at all ages under 75 and then sharply increased in the 1990s to values, with levels 18 to 22 percent higher than that in 1970-74. In the 1990s, mortality among Russian men at ages 65-74 and 75+ also increased significantly, eventually reaching a figure that is about 10 percent higher than in 1970-74. In Eastern Europe, mortality among men shows some signs of improvement in the 1990s.

Among women, mortality in Russia and Eastern Europe generally stagnated between 1970-74 and 1980-84 at all ages except those under 15, where it declines. The positive effects of the anti-alcohol campaign are seen in 1985-89 for Russia at all adult ages under 75 years for men and under 65 years for women. In the 1990s, adverse mortality trends among Russian women at all working and old ages contrast with a very significant downturn in Eastern Europe.

To conclude, since 1970 mortality trends in every age group have reflected the general health crisis in Russia. Although mortality of infants and children has been declining, this decline was slow. Mortality among men has increased in all adult age groups, especially at working ages. Mortality of adult women was stagnating in the 1970 s and the 1980s and deteriorated in the 1990s.

It is notable that the steepest mortality increase was observed among workingaged men. This group appears to be the most affected by the health crisis, while the traditionally vulnerable children and the elderly were less affected. ${ }^{14}$ In 2001 the probability that a 20 -year old man would survive to age 65 was 44 percent $v$ s. about 80 to 90 percent in western countries. In our earlier studies, we showed that mortality among adults had the strongest impact on changes in life expectancy at birth in the 1960s-1990s. ${ }^{15}$

13 In this section analysis begins from 1970 since quality of mortality statistics at advanced ages before 1970 was not high.

14 L. Chen, F. Wittgenstein, E. McKeon, 'The upsurge of mortality in Russia: causes and policy implication', Pop Dev Rev, 22 (1996), 517-530; Leon et al. (1997).

15 Meslé et al., (2000); V. M. Shkolnikov, G. A. Cornia, D. A. Leon, F. Meslé, 'Causes of the Russian Mortality Crisis: Evidence and Interpretations', World Development, 26 (1998), 19952011; V. M. Shkolnikov, F. Meslé, 'Russian epidemiological crisis as mirrored by mortality trends', in Russia's Demographic "Crisis", ed. J. DaVanzo (Santa Monica, CA, RAND, 1996), pp.113-162. 
Figure 3. Age distributions of the life table deaths for males (upper panel) and females (lower panel) in Russia, 2001 and the USA, 1998.
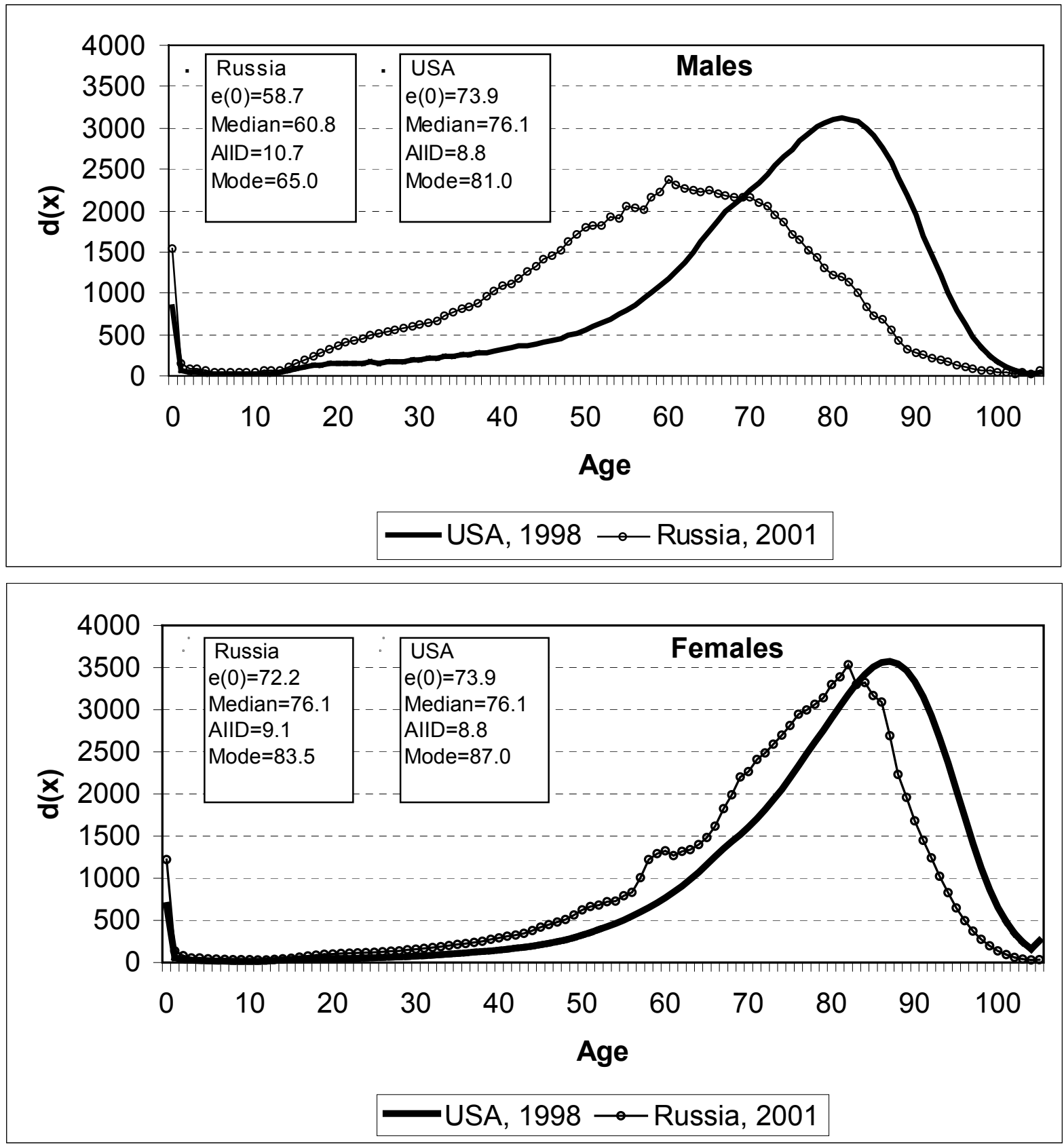

Source: Our calculations from the Human Mortality Database, 2004 data.

Figure 3 compares the age distributions of deaths $d(x)$ from period life tables in Russia and the USA. The latter country experiences a relatively high (by western standards) mortality at working ages and has in this sense some similarity with Russia. Figure 3, however, demonstrates a huge difference, favouring the USA over Russia. For men, not only is the average length of life shorter in Russia, but it is also more unequal, as measured by the average inter-individual difference in age of 
death (AIID) ${ }^{16}$. The shapes of the distributions are strikingly different. The Russian distribution has much larger tail on the left side, reflecting the large toll of premature death in infancy and, especially, in adulthood. In Russia 60 percent of male deaths occur under the age of 65. In the USA the equivalent proportion is only 25 percent. Thus, many fewer Russian men survive to the age when many of the common fatal diseases of industrialised countries could be expected to become apparent.

Among women, the difference between Russia and the USA is less dramatic since an overwhelming majority of deaths in both populations occur at old ages. However while the two distributions have similar shapes, the Russian situation is still considerably worse, being shifted leftwards by about 4 years compared to the US distribution. Premature deaths of women remain more frequent in Russia, with 25 percent of female deaths occurring under the age of 65 compared with 14 percent in the USA.

Modal age at death is usually considered an expression of the natural life span. ${ }^{17}$ A 16-year gap between the Russian and the US men tells that accelerated accumulation of health hazards over the life course leads to earlier aging of the Russian men. For women the Russia-US gap is much smaller.

\section{Causes of Death}

Figure 4 shows trends in the Russian mortality rates for a selection of 14 causes of death, divided into three groups. The first group of causes represents mortality from the main classes of chronic diseases such as ischaemic heart disease, cerebrovascular disorders, respiratory and infectious diseases. Tuberculosis constitutes over 80 percent of the last of these classes. Mortality from ischaemic heart disease and cerebrovascular disorders generally increase over the whole period, while mortality rates from respiratory and infectious diseases were decreasing until the beginning of the 1990s and then either levelled off (respiratory) or increased (infectious). Although none of these causes traditionally has been thought of as being caused by alcohol consumption, they all demonstrate significant fluctuations coinciding with the anti-alcohol campaign beginning in 1985. The observation that, since the beginning of the anti-alcohol campaign in 1985, trends in mortality

16 AIID $=\mathrm{G}(0)^{*} \mathrm{e}(0)$, where $\mathrm{G}(0)$ denotes the Gini coefficient of inter-individual inequality in age at death and $\mathrm{e}(0)$ is the average life expectancy at birth (see Shkolnikov, Andreev, Begun, 2003 for more details).

17 V. Kannisto, 'Measuring the compression of mortality', Demographic Research, 2000, volume 3, article 6, www.demographic-research.org. 
Figure 4. Age-standardized death rates per 100,000 for a selection of principal causes of death: Russia, 1965-2001.
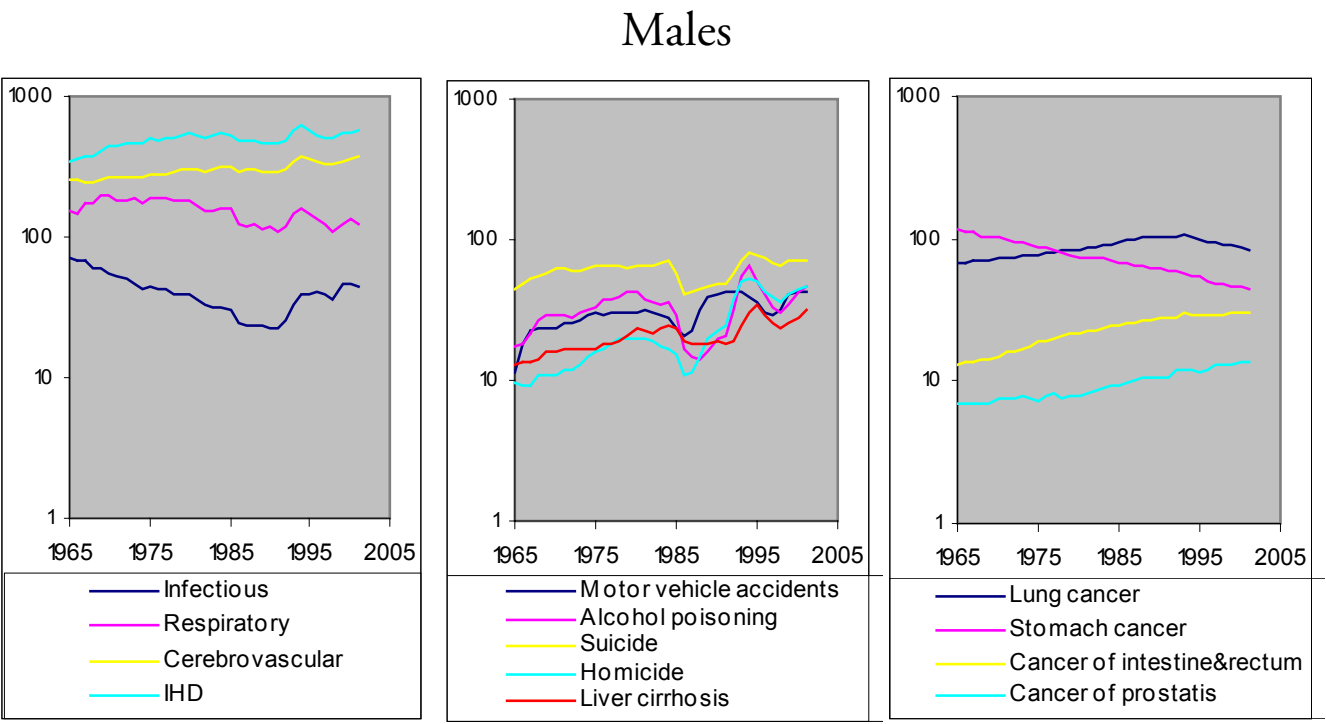

Females
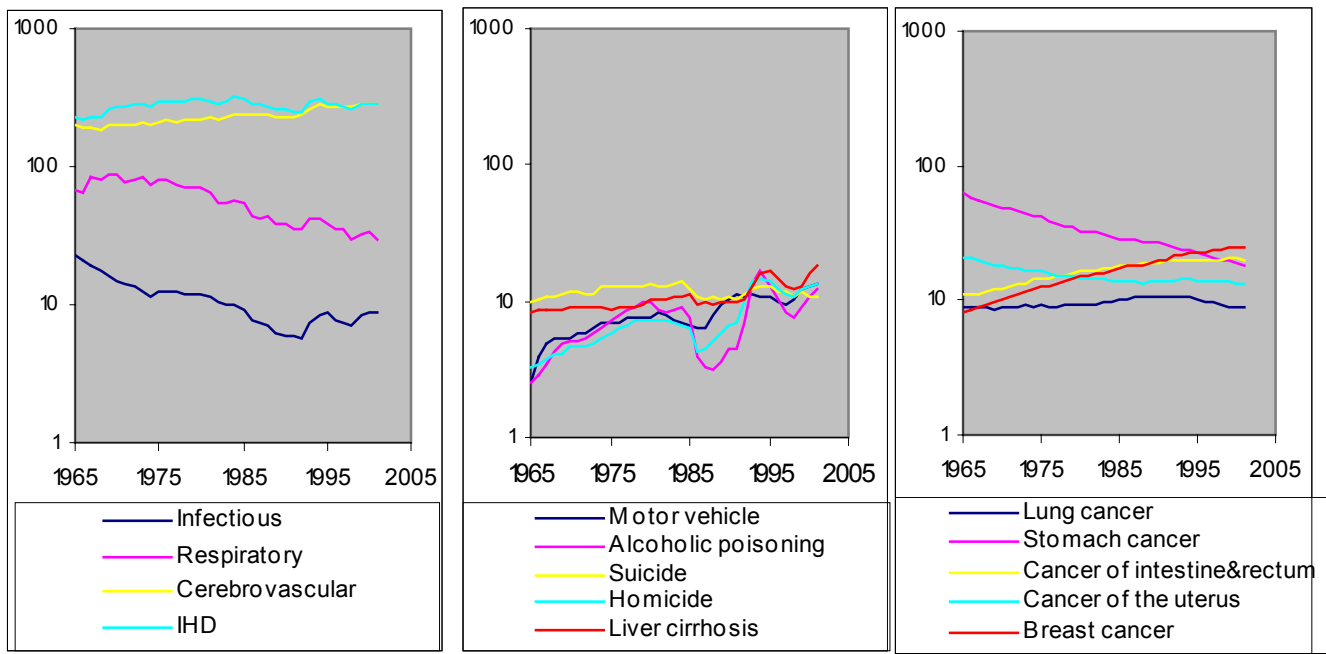

Note: The WHO European standard of the population age structure was used for standardization.

Source: Updated continuous series of causes of death for Russia (Meslé et al., 1996).

from the major cardiovascular diseases are so closely correlated with trends in violent and alcohol-related mortality is of a fundamental importance and will be discussed later in section 3.

The second group includes violent causes, motor vehicle injuries and causes directly connected with alcohol such as poisoning by alcohol and liver cirrhosis. Mortality rates from these causes also generally increased, experiencing large fluctuations after 1985. The proportional magnitude of these fluctuations is substantially greater than that in the first group of causes of death. The greatest 
proportional increase during the 1990s, and indeed over the whole period, is observed with homicide.

The third group of causes of death consists of cancers at the most frequent sites. They demonstrate long-standing and gradual increases or decreases, with no fluctuations due to period effects. In general, mortality from cancers is driven by biological factors and accumulated behavioural factors, often characterized by long time lags between exposure and illness. Mortality from stomach cancer continuously decreases as does mortality among women from cancer of the uterus, while mortality from cancer of the intestine and rectum, prostate, and female breast increases. Only mortality from cancer of the bronchus and lung, which has been increasing until the 1990s, turns downwards in the 1990s. However this unexpected change can be attributed to changes in the prevalence of smoking between birth cohorts and (perhaps) some problems in registration of causes of death. ${ }^{18}$ In general, Russia is characterized by relatively low female mortality from malignancies with an especially large gender gap in mortality from lung cancer.

For many causes of death, mortality trends for women are somewhat less adverse than those for men. One can also note several differences between sexes in relative levels and temporal changes among causes of death. Mortality from ischaemic heart disease in women has increased less than that in men, while mortality from cerebrovascular disorders has increased by about the same in both sexes. Consequently, the initial gap between these two causes has disappeared among women. Mortality from liver cirrhosis and homicide has become relatively more common among women than among men, while mortality from suicide among women has lost its highest position among external causes of death, another difference from men.

Additional comparisons with the USA, a country with a relatively high (by western standards) mortality from external causes, sheds further light on the present cause-of-death pattern in Russia. The first step is to examine the contributions of deaths at different ages and from different causes to the total life expectancy gap between the two countries. Then we will compare actual mortality rates for a more detailed list of causes of death.

18 V. Shkolnikov, M. McKee, D. Leon, L. Chenet, 'Why is the death rate from lung cancer falling in the Russian Federation?', Eur J. Epidemiol, 15 (1999), 203-206; V. M. Shkolnikov, M. McKee, J. Vallin, E. Aksel, D. Leon, , L. Chenet, F. Meslé, 'Cancer mortality in Russia and Ukraine: validity, competing risks, and cohort effects', International Journal of Epidemiology, 28, (1999), pp. 19-29. 
Figure 5. Decomposition of the US-Russia gap in life expectancy by age and major classes of causes of death. (USA, 1999 vs. Russia, 2001).
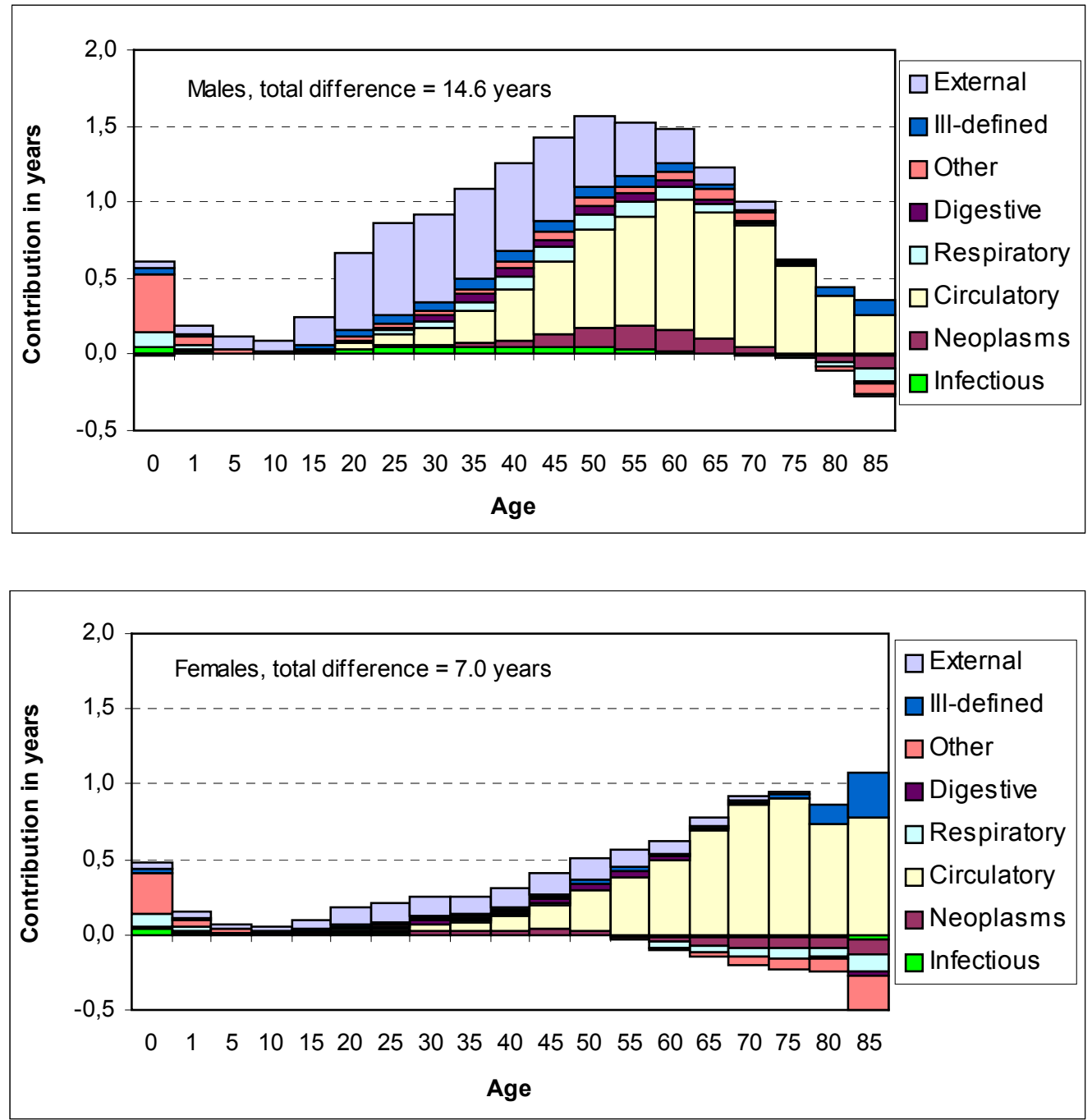

Source: Our calculations from the original Goskomstat's data for Russia and from the WHO Mortality Database of 2003.

Figure 5 shows that the overall gap for men is almost 15 years, with the greatest contribution being made by differences between mortality rates at ages from 40 to 65 years of age. Excess mortality in Russia from external causes (accidents, poisonings, and violence) plays a crucial role at ages between 20 and 50. At older ages circulatory diseases play a major part. The contribution made by cancers is considerable, but much less significant than those of cardiovascular and external causes. Respiratory diseases and infectious diseases contribute even less.

For women the gap in life expectancy at birth is 7 years and its structure by age and cause-of-death is quite different from that for males. First, the greatest contribution to the overall life expectancy gap is from excess mortality in Russia at ages over 60 . Second, cardiovascular diseases play a much greater role, with smaller 
Table 1. Age-standardized death rates for a selection of causes of death per 100,000 in Russia, 2001 and in the USA, 1999.

\begin{tabular}{|c|c|c|c|c|c|c|c|}
\hline \multirow{2}{*}{ Cause of death } & \multirow{2}{*}{ ICD-10 items } & \multicolumn{3}{|c|}{ Males } & \multicolumn{3}{|c|}{ Females } \\
\hline & & Russia & USA & Ratio & Russia & USA & Ratio \\
\hline Major classes & & & & & & & \\
\hline Total & $A A A$ & 2087.8 & 918.6 & 2.3 & 1024.2 & 613.2 & 1.7 \\
\hline Infectious & A00-A99,B00-B99 & 42.6 & 24.9 & 1.7 & 8.5 & 15.0 & 0.6 \\
\hline Neoplasms & C00-C97,D00-D48 & 282.4 & 233.7 & 1.2 & 136.9 & 160.3 & 0.9 \\
\hline Circulatory & I00-I99 & 1056.4 & 346.3 & 3.1 & 630.7 & 230.6 & 2.7 \\
\hline Respiratory & J00-J99 & 118.8 & 85.1 & 1.4 & 27.9 & 57.0 & 0.5 \\
\hline Digestive & K00-K93 & 65.8 & 33.3 & 2.0 & 31.0 & 21.8 & 1.4 \\
\hline Other & & 140.1 & 107.9 & 1.3 & 61.9 & 92.9 & 0.7 \\
\hline Ill-defined & R00-R94,R96-R99 & 85.5 & 8.8 & 9.7 & 56.1 & 6.3 & 8.9 \\
\hline External & V01-Y89 & 369.3 & 78.5 & 4.7 & 87.4 & 29.3 & 3.0 \\
\hline Selected causes & & & & & & & \\
\hline Tuberculosis & A15-A19 & 36.4 & 0.5 & 78.3 & 4.6 & 0.2 & 25.0 \\
\hline Cancer, aerodigestive & $\mathrm{C} 00-\mathrm{C} 15, \mathrm{C} 32$ & 22.0 & 14.1 & 1.6 & 3.1 & 3.7 & 0.9 \\
\hline Cancer, stomach & $\mathrm{C} 16$ & 42.9 & 5.9 & 7.2 & 17.9 & 2.9 & 6.2 \\
\hline Cancer, lung & C33-C34 & 94.7 & 72.8 & 1.3 & 9.6 & 39.0 & 0.2 \\
\hline $\begin{array}{l}\text { Cancer, intestine, rectum and } \\
\text { anus }\end{array}$ & $\mathrm{C} 17-\mathrm{C} 18$ & 29.2 & 23.0 & 1.3 & 19.6 & 16.0 & 1.2 \\
\hline Cancer, breast & $\mathrm{C} 50$ & 0.4 & 0.3 & 1.3 & 23.7 & 25.9 & 0.9 \\
\hline Cancer, uterus & C53-C55 & 0.0 & 0.0 & - & 13.2 & 6.7 & 2.0 \\
\hline Cancer, prostatis & C61 & 13.4 & 23.9 & 0.6 & 0.0 & 0.0 & - \\
\hline IHD & $\mathrm{I} 21-\mathrm{I} 25$ & 544.0 & 209.7 & 2.6 & 268.2 & 118.5 & 2.3 \\
\hline Cerebrovascular & I60-I69 & 351.3 & 49.3 & 7.1 & 267.9 & 45.3 & 5.9 \\
\hline Liver cirrhosis & $\mathrm{K} 70, \mathrm{~K} 74$ & 28.1 & 14.1 & 2.0 & 14.4 & 8.4 & 1.7 \\
\hline $\begin{array}{l}\text { Alc. psychosis, poisoning by } \\
\text { alcohol }\end{array}$ & F10, T51 & 45.5 & 4.1 & 11.2 & 12.0 & 0.9 & 12.8 \\
\hline Motor vehicle accidents & V01-V49 & 41.8 & 12.0 & 3.5 & 12.8 & 5.4 & 2.4 \\
\hline Accidental falls & W00-W19 & 16.1 & 5.5 & 3.0 & 4.1 & 2.7 & 1.5 \\
\hline Suicide & X60-X84 & 69.2 & 17.8 & 3.9 & 10.5 & 4.1 & 2.6 \\
\hline Homicide & $\mathrm{X} 85-Y 09$ & 44.5 & 9.4 & 4.7 & 13.0 & 2.9 & 4.4 \\
\hline
\end{tabular}

Note: The WHO European standard of the population age structure is used for standardization. Source: Our calculations from the original Goskomstat's data for Russia and from the WHO Mortality Database (2003) for the USA.

contributions from external causes of death. Cancers actually make a negative contribution, being lower in Russia than in the USA.

Table 1 shows in more detail the data on causes of death around the year 2000 with age-standardized death rates for major classes of causes of death and, within them, 16 specific causes. This shows the scale of the excess mortality in Russia across causes of death. Russia clearly combines extremely high mortality from natural and external causes. Mortality from ischaemic heart disease is 2.6 times higher than that in the USA among males and 2.2 times higher among females. The corresponding figures for cerebrovascular disorders are a 7-fold difference among males and a 6-fold difference among females. For stomach cancer the differences are 7-fold among males and 6-fold among females. For suicide, homicide, and motor vehicle accidents the differences are 3 to 4 -fold. 
Other causes of death, while less significant in terms of the absolute difference in overall mortality, are important because of what they contribute to understanding the nature of the Russian health crisis. Thus, although absolute numbers of death are small compared with, for example, ischaemic heart disease, the large relative differences in mortality from tuberculosis, causes directly related to alcohol, and liver cirrhosis are especially informative. Mortality from cancers of the breast and prostate are higher in the USA than those in Russia. Mortality from lung cancer is higher in Russia than that in the

USA for men and lower for women reflecting the traditionally low prevalence of smoking among the Russian women. ${ }^{19}$

In summary, compared with other industrialised countries, the high mortality in Russia is driven by three principal elements. First, the level of mortality from cardiovascular diseases in Russia is very high and there has not been the sustained decline over recent decades seen in other countries. While the burden of disease is exceptionally high among those of working ages, it is also relatively high among children and older men and women. Second, mortality from external causes, and in particular those associated with alcohol and with violence, is extremely high, pointing to the relationship between mortality, alcohol, and social stress. Third, there is a high mortality rate from causes amenable to health care, such as tuberculosis, hypertension and cerebrovascular diseases, indicating weaknesses of the health care system.

\section{Inequalities in the Face of Death}

So far this chapter has looked at aggregate mortality in the Russian population. It showed that great numbers of Russians, especially Russian men, die before reaching old ages. It is reflected by high values of average inter-individual difference in age at death in Russia (see Figure 3). Within this inter-individual inequality, there are significant differentials in mortality between socio-demographic groups, with mortality significantly higher among the single, the least educated and manual workers compared with the married, the highly educated and non-manual workers. ${ }^{20}$

19 M. McKee, M. Bobak, R. Rose, V. Shkolnikov, L. Chenet, D. Leon, 'Patterns of smoking in Russia', Tobacco Control, 7 (1998), 22-26.

20 V. M. Shkolnikov, E. M. Andreev, 'Differences by education and character of labor', in Neravenstvo i smertnost $v$ Rossii, [Inequality and Mortality in Russia] ed. Shkolnikov V. M., Andreev E. M., Maleva T. (Signal, Moscow, 2000), pp. 34-43. 
Figure 6. Temporary life expectancy between exact ages 20 and 70 in Russia, France, and the USA: annual figures for the total populations and estimates by educational group for 1979 and 1989.
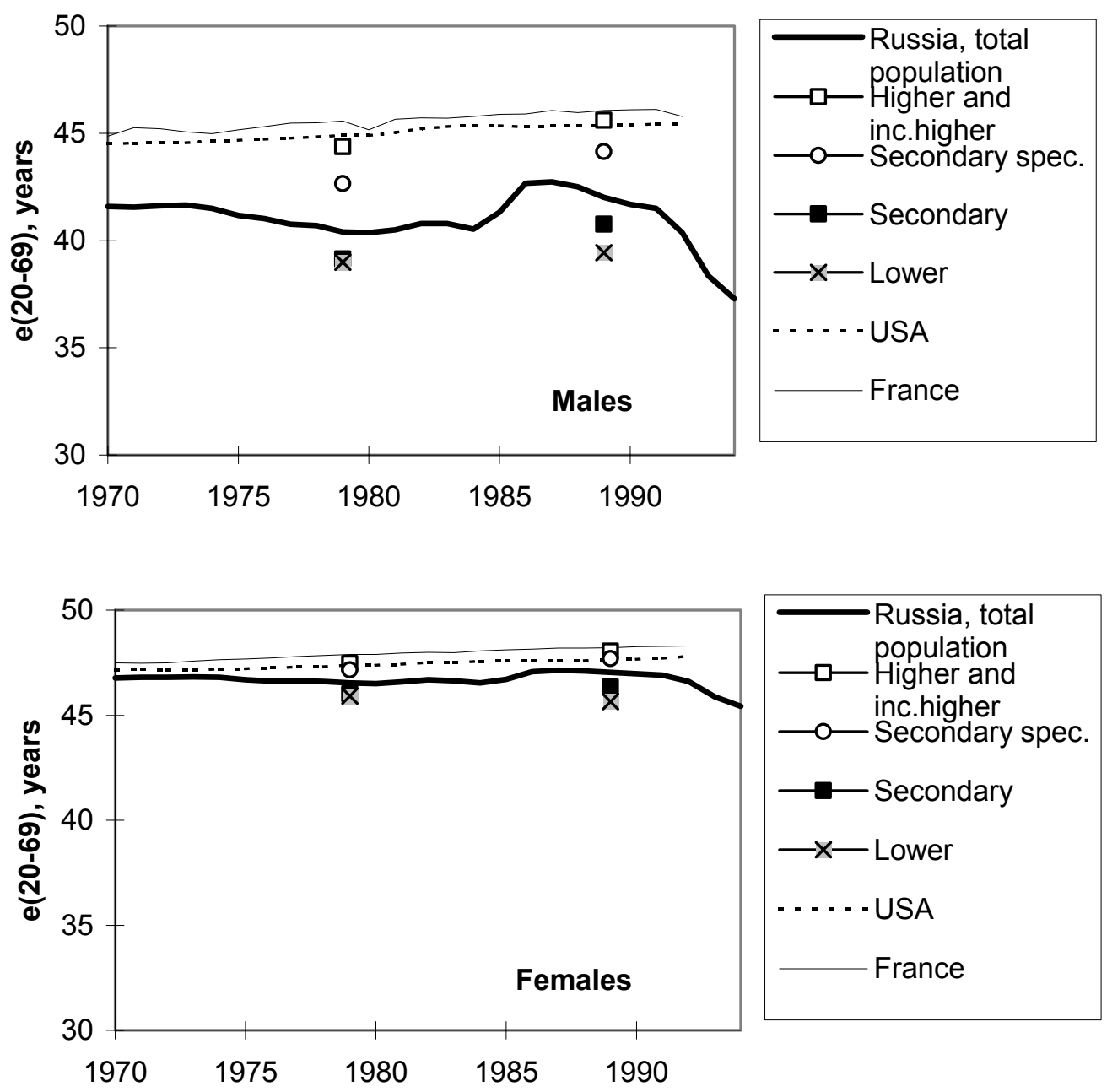

These inequalities have been longstanding, with a study of mortality at the time of the 1979 and 1989 censuses showing that life expectancy of Russians with university education was similar to the average in western countries while those with the least education very much lower ${ }^{21}$ (Figure 6). As in western countries, the educationrelated differential in mortality is greater for men than for women, it decreases slightly with age, and differs according to cause of death, with educational gradients insignificant or even reversed for some causes, such as cancer of the breast

21 Shkolnikov, Leon et al. (1998). 
Figure 7. Proportional differences in age specific death rates between the populations of lower and upper educational classes by cause of death at ages from 20 to $64,1989$.

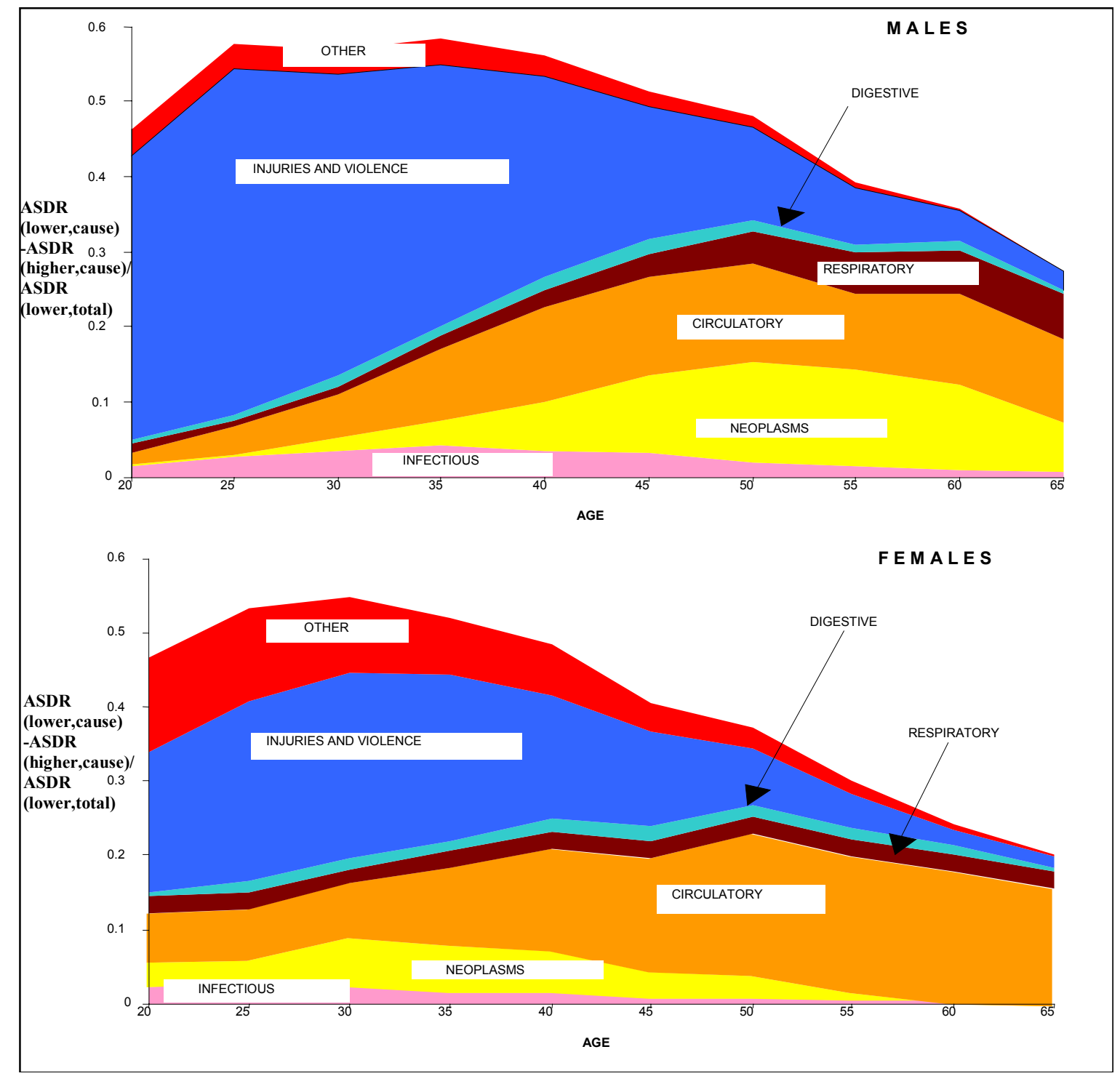

Notes: Lower educational class corresponds to secondary, incomplete secondary and lower education, upper educational class corresponds to higher (university), incomplete higher and secondarry special education.

Source: Shkolnikov, Leon et al., 1998.

or leukaemia, while being very large for others, such as lung cancer, tuberculosis, external and alcohol-related causes, and cardiovascular diseases. ${ }^{22}$

22 L. Chenet, D. Leon, M. McKee, S. Vassin, 'Deaths from alcohol and violence in Moscow: socio-economic determinants', Eur J Pop, 14 (1998), 19-37; Shkolnikov and Andreev, (2000); V. M. Shkolnikov, V. V. Chervyakov, Ed., Policies for the Control of the Transition's Mortality Crisis in Russia. Project No RUS/98/G51, UNDP/Russia, Moscow, 2000, 159 p. (In Russian and English languages). 
Figure 7 demonstrates that the contribution of deaths from different causes and at different ages to the educational gap in mortality in the Russian population is, in many ways, similar to that driving the gap between Russia and countries with low mortality, with cardiovascular diseases and external causes of death constituting most of the gap, although their relative weights vary by age.

These studies do, however, suffer from the limitation that they combine data on deaths and population from different sources (census self-reporting and postmortem reporting by relatives) and do not link them for each individual, which could produce numerator-denominator bias in estimates of mortality by population group. This disadvantage of unlinked mortality estimates made it difficult to draw definitive conclusions from the data or to make precise international comparisons. However a more recent study has been able to do this, taking advantage of data from a cohort of approximately 8,000 men from Moscow and St. Petersburg recruited to the Lipid Research Clinics (LRC) study in the mid 1970s, so avoiding the risk of numerator-denominator bias. It was found that the educational gradient in the largest Russian cities is steeper than those in Helsinki or Oslo, from where there were comparable data, both in absolute and relative terms ${ }^{23}$ (Tables $2 \& 3$ ). These findings have important implications for research on health inequalities elsewhere as, in Russia, the link between education and income has been quite different from that in the west, with many jobs requiring a high level of education bringing few financial rewards. ${ }^{24}$ Importantly, Table 2 also suggests that even the highest educational group in Russia experiences a substantially greater mortality than do equivalent population groups in low-mortality countries.

23 V. M. Shkolnikov, E. M. Andreev, A. Z. Begun, 'Gini coefficient as a life table function: computation from discrete data, decomposition of differences and empirical examples', Demographic Research. Vol. 8, article 11, 2003, www.demographic-research.org.

24 H. Domanski, 'Distribution of incomes in Eastern Europe', International Journal of Comp Sociol, XXXVIII (1997), 249-270; G. Pirogov, S. Pronin, 'The Russian case: social policy concerns', in Poverty in Transition and Transition and Transition in Poverty. Recent Developments in Hungary, Bulgaria, Romania, Georgia, Russia and Mongolia, Ed. Atal Y (New York, Oxford \& Paris, UNESCO, Publishing \& Bergham Books, 1999); Field M, 'The health crisis in the former Soviet Union: a report from the 'post-war' zone', Soc Sci Med, 41 (1995), 23-34; V. M. Shkolnikov, B. A. Rozenfeld, 'Zdravoohraneniye i Krizis Obschestvennogo Zdorovya v Rossii', ['The medical care and health crisis in Russia'] Komputerniye Tekhnologii v Medicine, 1 (1997), $18-23$. 
Table 2. Age-standardized* death rates for the range of ages 40 to 74 by level of education in three male cohorts: LRC (Moscow-St. Petersburg), Helsinki and Oslo (per 100,000 person-years lived between the mid-1970s and the late 1990s).

\begin{tabular}{llllc}
\hline City & Low & Middle & High & Total \\
\hline LRC (Moscow- & 2969 & 2019 & 1346 & $2194 / 2491^{* * *}$ \\
StPb) & $(192)^{* *}$ & $(151)$ & $(110)$ & $(82)$ \\
Helsinki & 1905 & 1405 & 974 & 1614 \\
& $(36)$ & $(44)$ & $(44)$ & $(24)$ \\
Oslo & 1731 & 1270 & 890 & 1407 \\
& $(48)$ & $(48)$ & $(50)$ & $(28)$
\end{tabular}

Ratios to the SDRs of the high education group

$\begin{array}{llllc}\text { LRC - Russia-StPb } & 2.2 & 1.5 & 1.0 & 1.6 / 1.7 \\ \text { Helsinki } & 2.0 & 1.4 & 1.0 & 1.7 \\ \text { Oslo } & 1.9 & 1.4 & 1.0 & 1.6\end{array}$

Ratios to the SDRs of Oslo

$\begin{array}{lllll}\text { LRC - Moscow- } & 1.7 & 1.6 & 1.5 & 1.4 / 1.6 \\ \mathrm{StPb} & & & \end{array}$

$\begin{array}{lllll}\text { Helsinki } & 1.1 & 1.1 & 1.1 & 1.1\end{array}$

Oslo $\quad 1.0 \quad 1.0 \quad 1.0 \quad 1.0$

Notes: *European population standard of the WHO is used. ${ }^{* *}$ Doubled standard errors are given in brackets. ${ }^{* * *}$ Actual value for the LRC cohort / expected value with the all-Russia educational composition.

Source: Shkolnikov, Deev et al, 2003

Table 3. Indices of inequalities based on age-standardized death rates of educational groups and their population weights.

Index of dissimilarity

(ID)

\begin{tabular}{cccc}
\hline $\begin{array}{c}\text { Relative } \\
(\%)\end{array}$ & $\begin{array}{c}\text { Absolute } \\
\text { (per 100000) }\end{array}$ & $\begin{array}{c}\text { Relative index } \\
\text { of inequality } \\
\text { (RII) (times) }\end{array}$ & $\begin{array}{c}\text { Slope index of } \\
\text { inequality (SII) (\%) }\end{array}$ \\
\hline 29.6 & 636 & 3.8 & 2587 \\
23.2 & 583 & 3.1 & 2530 \\
& & & \\
20.8 & 336 & 2.7 & 1467 \\
21.3 & 300 & 2.6 & 1251 \\
\hline
\end{tabular}

Note: See Shkolnikov, Deev et al, 2003 for details about calculation of indices of inequality.

Source: Shkolnikov, Deev et al, 2003. The indices are described in detail in the original paper.

Finally, there is also evidence suggesting that the striking mortality increase in the 1990s was concentrated among people with low levels of education. Analyses of the 
LRC data from both Moscow and St. Petersburg reveals no increase in mortality among men with university education, but a large increase in those with lower levels of education. ${ }^{25}$ It suggests that disadvantaged socio-demographic groups made a disproportionately high contribution to the mortality increase in the 1990s and that the current level of mortality in these groups is very high.

It is likely also that the socio-economic changes of the 1990s have resulted in a significant growth of marginalized groups such as people without permanent residence (homeless) or people exposed to the criminal justice system. Mortality in these groups, especially from certain "social" causes of death is likely to be at extremely high levels. Unfortunately, these groups are invisible in general mortality statistics and it is very difficult to reach by any kind of epidemiological study.

\section{Burden of Ill-Health and Health Expectancy}

This study has its main focus on mortality. However, mortality data provide only a partial picture of population health and, self-evidently, while past trends provide some indication of future prospects, they only relate to those who are no longer alive. This section provides a brief overview of knowledge about the overall burden of disease in the Russian population.

The pattern of mortality in Russia has certain specific features that complicate extrapolation from findings elsewhere. In particular, a disproportionate share of premature deaths are sudden, whether from injury or cardiovascular disease, from which deaths in Russia are much more likely to be sudden than elsewhere. ${ }^{26}$ For this reason, it might be expected that, despite the high death rate, rates of preceding morbidity might be unusually low. On the other hand, research from the early 1990s found that levels of self-rated poor health were much higher in Russia and Eastern Europe than in the west, perhaps reflecting an unknown amount of disabling, but less fatal conditions, such as those due to poor mental health. ${ }^{27}$

25 S. L. Plavinsky, S. I. Plavinskaya, A. N. Klimov, 'Social factors and increase in mortality in Russia in the 1990s: prospective cohort study', BMJ, 326 (2003), 1240-1242; VM Shkolnikov, A. D. Deev, Ø. Kravdal, T. Valkonen, 'Educational differentials in male mortality in Russia and northern Europe. A comparison of an epidemiological cohort from Moscow and St. Petersburg with the male populations of Helsinki and Oslo', Dem Res, 2003; 10: Article 1, www.demographic-research.org/.

26 M. McKee, V. Shkolnikov, D. A. Leon, 'Alcohol is implicated in the fluctuations in cardiovascular disease in Russia since the 1980s', Ann Epidemiology, 11 (2001), 1-6; D. B. Shestov, A. D. Deev, A. N. Klimov, C. E. Davis, H. A. Tyroler, 'Increased risk of coronary heart disease death in men with low total and low-density Lipoprotein Cholesterol in the Russian lipid research clinics prevalence follow-up study', Circulation, 88 (1993), 846-853.

27 P. Carlson,'Self-perceived health in East and West Europe: Another European health divide', Soc Sci Med, 46 (1998), 1355-1366. 
Clearly it is important to assess the scale of the overall burden of disability and premature death.

Direct use of morbidity statistics is problematic due to various biases related to the nature of these data. They depend on the methods of registration, availability of medical facilities, health seeking behaviour, clinical judgement, and many other factors. However, for certain categories of socially important diseases, there are special systems for registration and surveillance with standardized procedures for data collection. These exist for tuberculosis, sexually transmitted diseases, HIV, and some psychiatric disorders including alcohol and drug dependence. Estimates of incidence of these conditions can also be biased (mostly downward) due to the aforementioned factors, but they deserve serious attention since even existing official data look very worrying. Major concerns relate to steep rises of sexually transmitted diseases, HIV and tuberculosis.

The following data are taken from the section on population health of the $9^{\text {th }}$ annual report "Population of Russia"28. According to this source, annual number of patients with newly diagnosed syphilis increased from 5,000 to 278,000 between 1990 and 1997 and then decreased to 144,000. The latter decrease could be partly due to a spread of private medical practices offering anonymous treatment of this disease. In the second half of the 1990s Russia experienced a rapid growth of newly registered HIV cases from 1,500 in 1996 to 88,000 in 2001. In the middle of 2002 the total number of registered patients with HIV in Russia was 208,000. The overall number of deaths from AIDS among registered patients was 2,700. These numbers may reflect a rapid increase in the epidemic, but they are believed to underestimate its level. According to indirect estimates by UNAIDS ${ }^{29}$, the number of people with HIV in Russia in 2001 was about 700,000 and the number of deaths due to AIDS about 9,000 .

The number of newly registered cases of tuberculosis increased from about 30,000 to about 80,000 between 1990 and 2001 . The officially registered incidence of the disease was about 100 (140 for men and 40 for women) per 100,000 in 2001 . This level is about 2.5-fold higher than in Hungary, Bulgaria, and Slovakia, about 5-fold higher than in Czech Republic and about 10-fold higher than in Great Britain and the Netherlands.

In Russia both tuberculosis and HIV are concentrated among those of working age, from 15 to 50 . However, the major burden of chronic disease and ill-health at

28 B. B. Prokhorov, E. M. Andreev, V. I. Sakevich, 'Zdorovye', ['Health'] in Naseleniye Rossii 2001. Devyatiy Ezhegodniy Demografitcheskiy Doklad, [Population of Russia 2001. The Ninth Annual Demographic Report] ed. by. A.G.Vishnevski (INP RAN, Moscow, 2002), pp. 70-98.

29 UNAIDS, 2002. Russian Federation. Epidemiological Facts Sheets on HIV/AIDS and sexually transmitted diseases. 2002 update. Available at http://www.who.int/emchiv/fact sheets/pdfs/Russianfederation EN.pdf. 
middle and old ages remains invisible due to an absence of valid data on morbidity and health. Estimating health from survey data is a good alternative to using unreliable statistics. Such information can be combined with mortality data to yield levels of health expectancy, or the expectancy of being alive and either in good or poor health. ${ }^{30}$ We have undertaken this exercise in Russia, comparing it with countries in Western and in Eastern Europe on the basis of surveys of the mid1990s. ${ }^{31}$ The Russian health data were taken from the 1995 wave of the Russian Longitudinal Monitoring Survey ${ }^{32}$, while data for Western Europe (Belgium, France, UK, Italy, Spain, West Germany) and for Eastern Europe (Bulgaria, Czech Republic, Hungary, East Germany, Poland) were extracted from the World Value Surveys ${ }^{33}$.

Health status was derived from a standard question on self-rated health, which is widely regarded as a valid and reliable measure of health ${ }^{34}$, correlating well with other measures of morbidity. ${ }^{35}$ We found that the frequency of poor health increases with age much more rapidly in Russia than in Western Europe. For example, 20 percent of Russian men have unhealthy status by age 60-64 and 20 percent of Russian women have unhealthy status by age 50-54. The equivalent quintiles for Western Europe are 85+ and 75-79 years for men and women, respectively. ${ }^{36}$

The values of health expectancy are shown in Table 4. They are very low in Russia in the mid-1990s and there is a large gap between Russia and Eastern Europe on one side and Western Europe on the other with Russia being still worse than Eastern Europe. Importantly, Russian women seem to be carrying especially high burden of ill-health.

30 J-M. Robine, C. D. Mathers, M. R. Bone, I Romieu, eds., Calculation of health expectancies: harmonization, consensus achieved and future perspectives (London, John Libbey Eurotex, 1993); J-M. Robine, I. Romieu, E. Cambois, 'Health expectancy indicators', Bulletin of the WHO, 77(2), pp. 181-185, 1999; DF. Sullivan, 'A single index of mortality and morbidity', HSMHA health report, 86 (1964), 347-54.

31 E. M. Andreev, E Nolte, V. M. Shkolnikov, E. Varavikova, M. McKee, 'The evolving pattern of avoidable mortality in Russia', Int J Epidemiol, 32 (2003), 437-446.

32 RLMS. Russia Longitudinal Monitoring Survey. http://www.cpc.unc.edu/rlms/.

33 World Value Surveys, 2003. World Values Surveys and European Values Surveys 1981-1984, 1990-1993, and 1995-1997. Inter-University Consortium for Political and Social Research. ICPSR No 2790.

34 P. Martikainen, A. Aromaa, M. Heliovaara, T. Klaukka, P. Knekt, J. Maatela, E. Lahelma., 'Reliability of perceived health by sex and age', Soc Sci Med, 48 (1999), 1117-22.

35 O. Manor, S. Matthews, C. Power, 'Self-rated health and limiting longstanding illness: inter-relationships with morbidity in early adulthood', Int J Epidemiol, 30 (2001), 600-7.

36 Andreev et al., (2003). 
Table 4. Life expectancy $\mathrm{e}(\mathrm{x})$ and healthy life expectancy $\mathrm{h}(\mathrm{x})^{*}$ at different ages: Russia, Eastern and Western Europe (years).

\begin{tabular}{llcccccc}
\hline \multirow{2}{*}{ Sex } & \multicolumn{2}{c}{ Country/ } & \multicolumn{2}{c}{ At age 20 } & \multicolumn{2}{c}{ At age 40 } & \multicolumn{2}{c}{ At age 65 } \\
\cline { 3 - 7 } & \multicolumn{1}{c}{ Region } & $\mathrm{e}(\mathrm{x})$ & $\mathrm{h}(\mathrm{x})$ & $\mathrm{e}(\mathrm{x})$ & $\mathrm{h}(\mathrm{x})$ & $\mathrm{e}(\mathrm{x})$ & $\mathrm{h}(\mathrm{x})$ \\
\hline Males & Russia & 41.9 & 36.7 & 22.4 & 17.3 & 11.4 & 6.7 \\
& Eastern Europe & 49.1 & 41.9 & 26.6 & 20.5 & 12.7 & 8.3 \\
\multirow{2}{*}{ Females } & Western Europe & 54.5 & 50.4 & 31.2 & 27.6 & 15.0 & 12.5 \\
& Russia & 54.2 & 40.6 & 31.1 & 18.5 & 15.2 & 5.8 \\
& Eastern Europe & 56.8 & 44.5 & 32.8 & 22.7 & 15.9 & 9.3 \\
Female-male & Western Europe & 60.2 & 53.7 & 36.0 & 30.3 & 18.1 & 14.0 \\
gap & Russia & 12.3 & 3.9 & 8.7 & 1.2 & 3.9 & -0.9 \\
& Eastern Europe & 7.6 & 2.6 & 6.2 & 2.2 & 3.3 & 1.1 \\
& Western Europe & 5.7 & 3.3 & 4.8 & 2.7 & 3.1 & 1.5 \\
\hline
\end{tabular}

*Health expectancy is calculated by Sullivan's method ((Sullivan, 1964), (Robine et al.;1993)).

Source: Andreev, McKee, Shkolnikov, 2003.

Self-reported health data are subjective by nature. Thus, a note of caution is needed as the possibility that gender-specific cultural features could influence differences in self-reported health. ${ }^{37}$ However, our findings suggest that the relative advantage of Russian women in terms of life expectancy is not matched by an advantage in health expectancy. The prevalence of ill-health among older Russian women appears high and so far this has been poorly recognised.

Yet this, in retrospect, should not be surprising, given the ill fortune that contemporary elderly Russian women have accumulated throughout lives that spanned the second world war, illustrated by the observation that older Russian women are three times as likely as men of the same age to live alone and to live in poverty. This evidence supports the argument advanced by Aneshensel et $\mathrm{al}^{38}$ that adverse life events affect men and women differently, with men reacting to stress with hostility and anger, often accompanied by substance abuse, with fatal consequences, while women are more likely to respond with less frequently fatal affective or anxiety disorders.

37 R. Sadana, C. D. Mathers, A. D. Lopez, C. J. L. Murray, K. Moesgaard-Iburg, 'Comparative analysis of more than 50 household surveys of health status', in Summary Measures of Population Health: Concepts, Ethics, Measurement and Applications, editors Murray C.J.L., Salomon J. A., Mathers C. D., Lopez A. D. (Geneva, WHO, 2002), pp. 369-386.

38 C. S. Aneshensel, C. M. Rutter, P. A. Lachenbruch, 'Social structure, stress and mental health: competing conceptual and analytical models', Am Sociol Rev, 56 (1991), 166-78. 


\section{An explanatory Framework for the Mortality Reversal}

The mortality experience of a population is determined by factors acting at several levels. First, there are the immediate causes of death, captured by mortality statistics, such as cardiovascular diseases, cancers and injuries. These have already been discussed in some detail above. Underlying them are a series of proximate risk factors, often referred to as behavioural or lifestyle-related, some of which are well understood, at least in western industrialised countries, where they have been subject to research. However, as has been noted above, they include many factors that are less well understood. Underlying these factors, influencing patterns of exposure to them by, for example, constraining the choices that people can make, include a range of more distal factors, including poverty and inequality. Acting at all levels are a range of factors that fall within a broad psychosocial category, impacting directly on an individual's vulnerability or resilience to health threats as well as their ability to make healthy lifestyle choices. Once disease has occurred, the health care system influenced the outcome for the individual, as modern methods of diagnosis and treatment are increasingly able to prevent premature death. This chapter continues by looking at how these factors have contributed to the pattern of mortality in Russia.

\section{Echoes of the Past}

First, it is important to recognise how the health of the people of Russia today partly reflects a mixture of contemporary and historical circumstances, with individuals' health influenced by their accumulated experience throughout life. ${ }^{39}$ Most obviously, the enormous toll exacted by the terror in the 1930s, and then by the Second World War ${ }^{40}$, means that those now over the age of 60 are a selected group from a larger population. Those who were born or spent their early childhood at certain critical times, such as the famine of 1932-33 and suffering during WWII, have been bequeathed an increase risk of death. ${ }^{41}$ A study of the

39 D. A. Leon, 'Common threads: underlying components of inequalities in mortality between and within countries', in Poverty, Inequality, and Health, ed. D. A. Leon, G. Walt (Oxford, Oxford University Press, 2001), pp. 58-87.

40 M. Haynes, R. Husan, A century of state murder: death and policy in twentieth century Russia (London, Pluto Press, 2003).

41 B. Anderson, B. Silver,'Patterns of the cohort mortality in the Soviet Population', Pop Dev Rev, 15 (1989), 471-501. 
survivors of the siege of Leningrad found increased blood pressure and a greater risk of cardiovascular death than in those not caught up in the siege. ${ }^{42}$

The link between adverse circumstances in childhood and adult mortality is especially strong for some diseases, such as stomach cancer, which arises following infection with a bacterium, heliicobacter pylori, which is most commonly acquired in childhood. However the association between life events and adult mortality can also be seen in the case of lung cancer, mortality from which provides an indicator of historical smoking rates in a population, with a lag between the age of taking up smoking and the maximum death rate being about 40 years. An age-cohort analysis of lung-cancer mortality suggests that smoking rates were high among Russian men reaching adulthood in the post World War II period and especially high among those reaching adulthood during the war ${ }^{43}$. The incidence of breast cancer today can be partly explained by childbearing histories and even in utero growth of women. ${ }^{44}$ It could be that circumstances in early life or early adult life affect today's levels of prostate cancer. ${ }^{45}$

In summary, an understanding of contemporary mortality in Russia must take account of events and conditions in the past. In particular, generally high level of stomach cancer and its continuous decline, increasing breast cancer and somewhat elevated mortality in cohorts of the early 1930s and 1940s can be at least partly attributed to echoes of the past. However, our prior analyses suggest that these causes of death are not the major components of the high level and unfavourable dynamics of Russian mortality. They can explain only a small part of temporal changes in mortality between the 1960s and 1990s. In particular, they cannot explain the large fluctuations in mortality experienced since the mid-1980s, for which other explanations must be sought. The following sections examine the role of, first, certain behavioural and lifestyle factors, specifically alcohol, tobacco, and poor nutrition, before moving on to look at the psychosocial response to communism and subsequent political and socio-economic transition.

42 P. Sparen, D. Vagero, D. B. Shestov, S. Plavinskaja, N. Parfenova, V. Hoptiar, D. Paturot, M. R. Galanti, 'Long term mortality after severe starvation during the siege of Leningrad: prospective cohort study', BMJ, 328 (2004), 11.

43 V. M Shkolnikov, M. McKee, J. Vallin, E. Aksel, D Leon, L. Chenet, F. Meslé, 'Cancer mortality in Russia and Ukraine: validity, competing risks, and cohort effects', International Journal of Epidemiology, 28, (1999), pp. 19-29.

44 D. A. Leon, (2001); G. Davey Smith, D. Gunell, Y. Ben-Shlomo, 'Life-course approaches to socio-economic differentials in cause-specific motality', in Poverty, Inequality, and Health, ed. D. A. Leon, G. Walt. (Oxford, Oxford University Press, 2001), pp. 88-124; IDS Silva, V. Beral, 'Socioeconomic differences in reproductive behaviour', in Social Inequalities and Cancer, eds. Kogevinas M, Pearce N, Susser M, Bofetta P (Agency for Research on Cancer, 1997), pp. 285-308.

45 Leon, (2001). 


\section{Smoking}

Figure 8. Cohort survival rate at ages from 40 to 80 by smoking status estimated from the Moscow and St.Petersburg Lipid Research Clinics data.

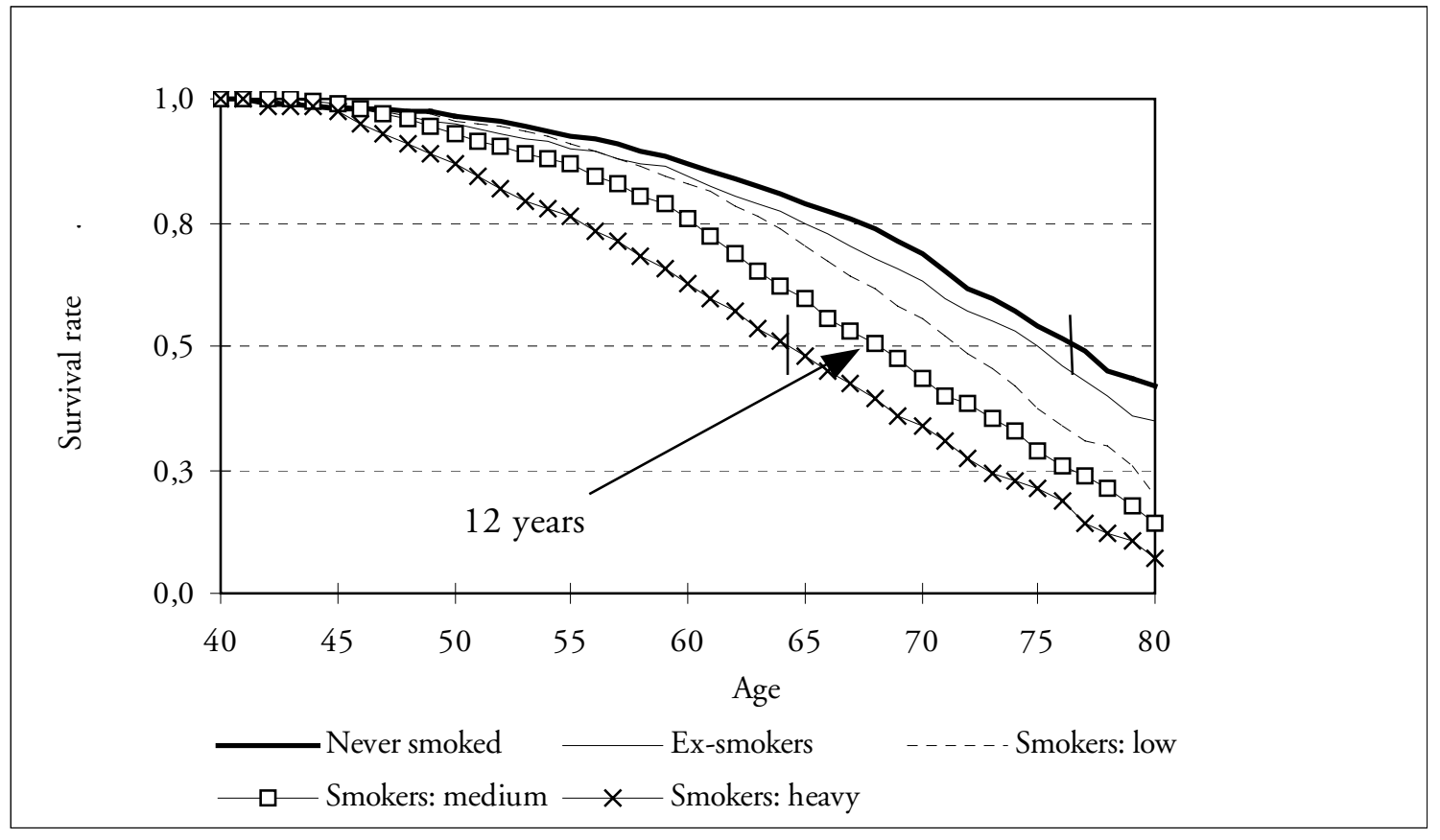

Note: Low smoking stands for less than 15 cigarettes per day, medium smoking stands for 15 to 19 cigarettes per day, heavy smoking stands for $20+$ cigarettes per day.

Source: Deev and Shkolnikov, 2000.

As in all industrialised countries, tobacco is a major cause of premature mortality. In Russia, data from the 1970s-1990s, from the LRC cohort, show that the impact of smoking on survival in Russians is large and entirely consistent with what has been observed elsewhere. Figure 7 shows a 12-year gap in median life expectancy between men who have never smoked and men who smoked 20 or more cigarettes daily. Analysis of relative risks by causes of death in the same cohort shows that (as elsewhere) smoking is associated with lung cancer, ischaemic heart disease and cerebrovascular disorders. ${ }^{46}$

Smoking is widespread among Russian men, with about 55-60 percent of adult men smoking in the 1980s and 90s. ${ }^{47}$ During World War II the Soviet authorities made strenuous efforts to ensure that cigarettes, at least, were available to the Red Army, with Stalin issuing an order to the party chief in Abkhazia, a tobacco

46 A. Deev, V. Shkolnikov, 'Neodnorodnost' smertnosti: amaliz individualnikh dannyh', ['Heterogeneity of mortality: analysis of individual-level data'] in Neravenstvo i Smertnost v Rossii [Inequality and Mortality in Russia], Eds., Shkolnikov V., Andreev E., Maleva T. (Moscow, Carnegie Center, 2000).

47 McKee et al. (1998). 
growing area in Georgia, to increase production to supply those on the front line at Stalingrad. ${ }^{48}$ As already noted, there is evidence of a cohort effect in lung cancer mortality, reflecting trends in uptake of smoking among young men. This is consistent with the knowledge that, as soon as the war ended, the struggle to rebuild war-damaged infrastructure and to industrialise the USSR took priority over production of consumer goods, including cigarettes. Young men reaching adulthood at this time thus carried with them a lower frequency of smoking. Finally, the situation again reversed in 1953 with the death of Stalin, as Khrushchev redressed the balance in favour of consumer goods and uptake of smoking among a new generation of young men increased.

Existing evidence suggests that smoking has increased during the 1990s in the former Soviet Union and that content of noxious substances in cigarettes is higher than in cigarettes consumed in western countries ${ }^{49}$. In the 1990s Russia's borders were opened to the transnational tobacco companies. They brought aggressive new marketing and distribution methods, paradoxically at a time when smoking rates in the west were falling, linking smoking with images of westernisation. ${ }^{50}$ Subsequently they established a manufacturing presence, allowing them to use arguments about employment as a means of influencing tobacco control policies. ${ }^{51}$ As a consequence, smoking rates among Russian men rose further, reaching 60-65 percent. ${ }^{52}$ However the most important consequence of the influx of western tobacco companies has been the increase in smoking among Russian women, a group whose smoking rates were traditionally low. ${ }^{53}$

Our study on cardiovascular deaths of men aged 20 to 55 found that high prevalence of smoking among Russian men and the associated cardiovascular hazard resulted in a very high population attributable risk of 41 percent. ${ }^{54}$ This estimate

48 S. Seebag-Montefiore, Stalin. The court of the red Tsar (London, Weidenfeld \& Nicholson, 2003).

49 A. Prokhorov, 'Cigarette smoking and priorities for tobacco control in the Newly Independent States', in Premature Death in the New Independent States, eds. J.-L. Bobadilla, C.A.Costello, and Faith Mitchell (National Academy Press, 1997), pp. 275-286.

50 A. Gilmore, M. McKee, 'Moving east: how the transnational tobacco companies gained entry to the emerging markets of the former Soviet Union. Part I: Establishing cigarette imports', Tobacco Control, 13 (2004), 143-150.

51 Gilmore and McKee, (2004).

52 N. Zohoori, L. Henderson, K. Gleiter, B. Popkin, Monitoring Health Conditions in the Russian Federation: The Russia Longitudinal Monitoring Survey 1992-2001. Report submitted to the U.S. Agency for International Development. (Carolina Population Center, University of North Carolina at Chapell Hill, North Carolina, 2002); McKee, Bobak et al. (1998).

53 A. B. Gilmore, J. Pomerleau, M. McKee, R. Rose, C. W. Haerpfer, D. Rotman, S. Tumanov, 'Prevalence of smoking in eight countries of the former Soviet Union: results from the Living conditions, Lifestyles and Health study', Am J Publ Health, (in press).

54 V. M. Shkolnikov, Meslé and Leon, (2002). 
corresponds well with the 45 percent estimate by Peto et al. ${ }^{55}$. Smoking could be responsible for a substantial part of high basic level of mortality, but it cannot explain the mortality fluctuations after 1985 and especially the sharp mortality increase in the 1990s. It is actually the reverse since (as we saw) there was some decrease in mortality from lung cancer in the second half of the 1990s.

\section{Alcohol}

It is impossible to ignore the impact of alcohol on Russian society, even leaving apart its impact on mortality. Commentators have described the consequences of heavy drinking in Russia since at least the thirteenth century ${ }^{56}$. The reasons why alcohol plays this role are, inevitably, complex. They include climatic conditions, with the major source of sugar for fermentation being grain rather than grapes, leading to a drinking culture based on spirits rather than wine, as well as living conditions that are shaped by long, cold and dark winters in which social interaction is often dominated by heavy drinking. In these respects, Russia is not unique, and populations at the same latitude, such as the Nordic countries in the past have experienced similar problems. ${ }^{57}$ However a second set of factors relate to governmental policies on alcohol. In imperial Russia the Tsars held a monopoly on alcohol production and sales, yielding about a third of their total income. There was an obvious disincentive to do anything that would disrupt this flow of revenue. At the same time, alcohol, or more explicitly, drunkenness, was seen as a means of keeping the masses compliant. The situation changed briefly in the period between 1919 to 1926 during the New Economic Programme instituted by the Bolshevik government after the October revolution, when Lenin sought to reduce the supply of alcohol because of its damaging effects on the economy. But the lure of revenue from its sale was too enticing and in 1926 the restrictions were terminated by Stalin, who needed the money to pay for industrialization. Importantly, in a society that produced virtually no consumer goods, it provided one of the very few means of recirculating roubles. By the 1980s, however, when the stagnation of mortality could no longer be ignored, as well as the major negative impact that alcohol was having on economic production through absence from work or inebriation at work, it became necessary to act. The ability to do so arose when Gorbachev emerged as the first secretary of the Communist party, launching his campaigns of glasnost and perestroika together with a wide ranging anti-alcohol campaign, the effects of which have been noted previously.

55 Peto et al. (1994).

56 M. McKee, 'Alcohol in Russia', Alcohol Alcoholism, 34 (1999), 824-829.

57 Wilner, 1999 
These historical reasons as well as contemporary socio-psychological conditions, contribute to high alcohol consumption in Russia. At present, official statistics are misleading because of under-recording of sales and illegal production. However estimates derived using a variety of methods suggest that its true level is probably between 12 and 15 litres of pure ethanol per capita per year. ${ }^{58}$ It is now widely agreed that alcohol has been especially important in the sharp fluctuations in life expectancy since the middle of the 1980s, with the imposition of the anti-alcohol campaign and its subsequent abandonment. ${ }^{59}$

It is increasingly recognized also that the damaging effects of alcohol consumption in Russia stem not only from the quantity consumed but also the way it is consumed. ${ }^{60}$ Unlike, for example, Mediterranean countries, where significant amounts of alcohol are consumed, but in a regular daily pattern, often with meals, in Russia the same weekly amount is more likely to be consumed on a single occasion $^{61}$, a pattern that has been termed binge drinking or episodic heavy drinking. Thus, in one study, 31 percent of Russian men admitted to drinking at least $25 \mathrm{cl}$ of vodka at one go at least monthly, and this figure is likely to be an underestimate. ${ }^{62}$

Quite clearly, alcohol is directly and causally involved in a range of causes of death such as acute alcohol poisoning and the chronic effects of alcohol exposure on various organs, including the liver (cirrhosis), the heart (alcoholic cardiomypoathy), the brain (stroke and micro-vascular dementia). However it also predisposes individuals to a much wider range of causes of death. These are, first of all, various types of external causes. ${ }^{63}$ Some, such as many types of injury and violence, arise as a consequence of inebriation, with the effects not only limited to those who are drunk but extending to those who come in contact with them. The obvious example is driving while drunk. A study of the very high rate of homicide in Russia found that a very high proportion of both victims and perpetrators were drunk at

58 Nemtsov, (2002); V. Treml, 'Soviet and Russian statistics on alcohol consumption and abuse', in Premature Death in the New Independent States, Eds. Bobadilla, J.-L., Costello, C. and Mitchell, F. (Washington DC, National Academy Press, 1997), pp. 220-238; J. Simpura, B. Levin (eds.), Demystifying Russian Drinking. Comparative Studies from the 1990s. Research Rep 85. (Helsinki, Gummerus Kirjapaino OY, 1997).

59 Shkolnikov et al. (1998); Avdeev et al. (1998); W. C.. Cockerham, Health and Social Change in Russia and Eastern Europe (Routledge, New York, 1999).

60 Treml, (1997); Nemtsov, (2002).

61 P. Carlson, D. Vågerö, 'The social pattern of heavy drinking in Russia during transition: evidence from Taganrog 1993', Eur J Publ Health, 8 (1998), 280-285.

62 M. Bobak, M. McKee, R. Rose, M. Marmot, 'Alcohol consumption in a national sample of the Russian population', Addiction, 94 (1999), 857-66.

63 Meslé et al. (1994). 
the time of the murder. ${ }^{64}$ Subsequent work has demonstrated the close geographical association between homicide rates and indicators of heavy alcohol consumption in Russia. ${ }^{65}$ However an examination of trends in mortality following the 1985 antialcohol campaign suggests that the effects of heavy drinking may be even greater than this, with large fluctuations in deaths from pneumonia occurring simultaneously with those more directly associated with alcohol. This association is plausible, given the risk of aspiration of vomit by those who are drunk, as well as the depressed immune function found in heavy drinkers. The latter effect also contributions to the association between heavy alcohol consumption and tuberculosis.

Earlier we also demonstrated that cardiovascular causes of death exhibited the same fluctuations associated with the anti-alcohol campaign and further sharp changes in alcohol consumption. These observations challenge the conventional view that alcohol consumption is cardioprotective, with one authoritative source arguing that this effect extended to "all levels of consumption". ${ }^{66}$ Since then, a systematic review ${ }^{67}$ has shown that, while regular moderate consumption does appear to be cardioprotective, at least in the populations in which it has been studied, episodic heavy consumption is likely to be causally associated with cardiovascular death, in particular sudden death among young men. That study also explored the potential mechanisms that could explain this apparent paradox and found that the effects of the two patterns of drinking differ markedly for a range of physiological measures, involving lipid metabolism, blood clotting, and myocardial irritability, with in each case the effect of episodic heavy consumption favouring sudden cardiac death. ${ }^{68}$ These findings have led to a reassessment of the role of alcohol in cardiovascular disease, with researchers demonstrating similar effects in other populations where episodic heavy drinking is common. ${ }^{69}$ For completeness, it should be noted that a suggestion that this association may be due to misattribution

64 V. V. Chervyakov, V. M. Shkolnikov, W. A. Pridemore, M. McKee, 'The changing nature of murder in Russia', Soc Sci Med, 55 (2002), 1713-1724.

65 W. A. Pridemore, 'Vodka and violence: alcohol consumption and homicide rates in Russia', Am J Public Health, 92 (2002), 1921-30.

66 C. J. L. Murray, A. D. Lopez (eds)., The global burden of disease (Boston MA, WHO, Harvard School of Public Health, World Bank, 1996), pp 307-8.

67 A. Britton, M. McKee, 'The relationship between alcohol and cardiovascular disease in Eastern Europe: explaining the paradox', J Epidemiol Comm Health, 54 (2000), 328-332.

68 M. McKee, A. Britton, 'The positive relationship between alcohol and heart disease in eastern Europe: potential physiological mechanisms', J. R. Soc.Med., 91 (1998), 402-7.

69 P. Mäkelä, T. Valkonen, K. Poikolainen, 'Estimated numbers of deaths from coronary heart disease "caused" and "prevented" by alcohol: an example from Finland', J Studies Alcohol, 58 (1997), 455-463; C. Evans, J. Chalmers, S. Capewell, A. Redpath, A. Finlayson, J. Boyd, J. Pell, J. McMurray, K. Macintyre, L. Graham, "I don't like Mondays” day of the week of coronary heart disease deaths in Scotland: study of routinely collected data', BMJ, 320 (2000), 218-219. 
of sudden deaths actually due to alcohol poisoning does not seem to be the case. In our prior study on this matter, we found elevated levels of alcohol among men, who died from (officially registered) cardiovascular causes at ages from 20 to $55^{70}$ However, blood concentrations of alcohol were much lower than they should be in cases of alcohol poisoning.

Several important epidemiological studies have failed to explain high cardiovascular mortality in the former Soviet Union and Russia by conventional mechanism of atherosclerosis related to gradual cumulation of hazard due to cholesterol and smoking. ${ }^{71}$

These findings, and the significant fluctuations in cardiovascular mortality during and after the natural experiment of the anti-alcohol campaign, indicate the importance of non-conventional mechanisms of cardiac pathology described by Britton and $\mathrm{McKee}^{72}$ and probably effects of interactions with additional factors such as psychosocial stress or medical care.

At the same time, there is already a first piece of direct individual-level evidence linking binge drinking with early deaths from cardiovascular diseases. Our recent case-control study of deaths of men aged 20 to 55 in Udmurtyia, revealed two different types of relationship with alcohol for violent and cardiovascular deaths. ${ }^{73}$ Risk of death from accidents and violence was associated with any alcohol drinking, whereas the risk of cardiovascular death was associated with heavy doses of alcohol only and did not depend on drinking alcohol as such.

In summary, there is now compelling evidence that alcohol directly and indirectly plays a major role in both the high underlying mortality in Russia and, in particular, the fluctuations that have occurred in the period since the 1980s. Of

70 V. M. Shkolnikov, M. McKee, V. V. Chervyakov, N. A. Kyrianov., 'Is the link between alcohol and cardiovascular death among young Russian men attributable to misclassification of acute alcohol intoxication? Evidence from the city of Izhevsk', $J$ Epidemiol Comm Health, 56 (2002), 171-174.

71 A. M. Vikhert, V. G. Tsiplenkova, N. M. Cherpachenko, 'Alcoholic cardiomyopathy and sudden cardiac death', J Am Coll Cardiol, 8 (1986), 3A-11A; E. Ginter, 'Cardiovascular risk factors in the former communist countries. Analysis of 40 European MONICA populations', Eur J. Epidemiol, 11 (1995), 199-205; B. H. Dennis, G. S. Zhukovsky, D. B. Shestov, C. E. Davis et al., 'The association of education with coronary heart disease mortality in the USSR Lipid Research Clinics Study', Int. J. Epidemiol 22 (1993), 420-427; M. Kristenson, Z. Kucinskiene, 'Possible causes of differences in coronary heart disease mortality between Lithuania and Sweden: the LiVicordia Study', in Heart Disease: Environment, Stress, and Gender, ed. by G. Weidner, M. Kopp, M. Kristenson. (Amsterdam, IOS Press, 2002), pp. 328-340; M. Averina, O. Nilssen, T. Brenn, J. Brox, A. G. Kalinin, V. L. Arkhipovsky, 'High cardiovascular mortality in Russia cannot be explained by the classical risk factors. The Arkhangelsk Study 2000', Eur J Epidemiol, 18 (2003), 871-8.

72 Britton and McKee, (2000).

73 Shkolnikov, Chervyakov et al. (2004). 
course, this then raises a further question; why do Russians drink in such a hazardous way? That issue will be returned to later.

\section{Nutrition}

As with alcohol, research in the former Soviet Union is providing new perspectives on the role of nutrition in health. The relationship between macronutrient intake and disease is well understood but, as already noted, there is evidence that lipids, perhaps the most extensively studied diet-related risk factor, do not behave in the same way in Russians as in western populations, at least in explaining variations in cardiovascular disease. Nonetheless, there are many reasons to avoid a diet that is high in fat and low in carbohydrates. Yet this is the opposite of the standard Russian diet, in which consumption of bread and potatoes decreased between the 1960s and the late 1980s, while consumption of meat, eggs and diary increased so that, by the end of the 1980s, consumption of fat was 10-15 percent higher than that recommended by the WHO. ${ }^{74}$ However, during the 1990 s, consumption of more expensive diary and meat products decreased, while consumption of cereals increased. In the mid-1990s the level of energy received from fat was around the norm. Despite increasing impoverishment, there is no evidence of widespread malnutrition. ${ }^{75}$ Yet energy intake is only one half of the equation. It is essential to consider overall energy balance, looking at the level of participation in exercise, and thus energy expenditure. What evidence exists suggests that this is very low in the Russian population, contributing to rising levels of obesity. ${ }^{76}$

It is, however, micronutrient intake that has attracted most attention ${ }^{77}$, including evidence of a high rate of anaemia among women and children $^{78}$ and low consumption of fresh fruits and vegetables. These are increasingly recognised as

74 N. G. Kisseleva, 'Nutrition'. Annex 7.3. in Inception Report: Preventive Health Care. Tacis-project, Annexes, Volume II. (Moscow, 1998).

75 B. M. Popkin, N. Zohoori, L. Kohlmeier, A. Baturin, A. Martinchik, A. Deev, 'Nutritional risk factors in the former Soviet Union', in Premature Death in the New Independent States, Eds. Bobadilla, J.-L., Costello, C. and Mitchell, F. (Washington DC, National Academy Press, 1997), pp. 314-334.

76 H. Palosuo, I. Zhuravleva, A. Uutela, N. Lakomova, L. Shilova, Perecived Health, Health-Related Habits and Attitudes in Helsinki and Moscow: A Comparative Study of Adult Populations in 1991. A10/1995. (Helsinki, National Public Health Institute, 1995).

77 R. Paniccià, 'Transition, impoverishment, and mortality: how large an impact?', in The mortality crisis in transitional economies, Ed. by G.A. Cornia, R.Paniccià. (Oxford, Oxford University Press, 2000), pp. 105-126.

78 Prokhorov et al., (2002). 
having an essential role in protecting against cardiovascular disease and some cancers. $^{79}$

\section{The Inadequacies of the Health Care System}

The issue to be considered is the way in which the Soviet, and subsequently Russian health care system has responded to the principal health challenges of the time.

The creation of the Soviet health care system represented a tremendous achievement. Before the liberation of the serfs in 1861, health care in rural Russia was virtually non-existent. Although a basic system was put in place after 1864 as part of Tsar Alexander II's implementation of the 'zemskii vrach' system of local government, whose responsibilities included health ${ }^{80}$, but even by the end of the nineteenth century the situation in many remote areas was extremely rudimentary. ${ }^{81}$

The Bolsheviks gave a high priority to health, in particular prevention, faced with widespread epidemics of typhus following the civil war. The pre-war Soviet government developed a widespread network of health facilities. This included a hierarchy of hospitals, from the most specialised all-Union facilities in Moscow to small district ones, with only a few beds and the most basic of facilities. A leading role was given to the policlinic, staffed by district physicians (uchastkovii vrach), each serving a geographically defined population, typically of 1,700 adults (or 1,200 children), complemented by 'outpatient specialists'. The system was, however, highly fragmented, also having specialised outpatient dispensaries caring for patients with specific diseases (e.g. tuberculosis, oncology, sexually transmitted diseases, mental disorders, and addictions), as well as parallel systems for those in certain occupations, such as the military or the railway system (or the nomenklatura, in the elite facilities of the Fourth Directorate of the Ministry of Health). The Soviet model favoured cities rather than rural areas ${ }^{82}$, the parallel systems rather than those providing for the majority of the population, and hospitals rather than primary

79 K. Lock, J. Pomerleau, L. Causer, M. McKee, 'Low fruit and vegetable consumption', in Comparative Quantification of Health Risks: Global and Regional Burden of Disease Due to Selected Major Risk Factors, eds. Ezzati M., Lopez A. D., Rodgers A., Murray C. J. L. (Geneva, WHO) (in press).

80 P. Krug, 'The Debate over the Delivery of Health Care in Rural Russia: The Moscow Zemstvo, 1864-1878', Bull History Med, 50 (1976), 226-241.

81 A. P. Chekhov, The island: a journey to Sakhalin (London, Pimlico, 1987).

82 C. Davis, The economics of the Soviet health system (Cambridge, Cambridge University Press, 1979). 
care $^{83}$ However it did manage to deliver universal access to basic care to an extremely dispersed population. ${ }^{84}$

Yet even in the 1960s weaknesses in the system were already appearing. ${ }^{85}$ The health system was funded on the "residual" principle; in other words it received what was left when other needs, such as those of the military-industrial complex, had been met. ${ }^{86}$ As other priorities gained more importance, the health system's share of a shrinking economy declined further, from an estimated 6 percent of GDP in the 1960 s to 3 percent in the late $1980 s^{87}$ The signs of decline were everywhere. The primary care system, which had been held up by the USSR as an example to the world at the World Health Organization's Alma-Ata conference ${ }^{88}$, was increasingly seen as ineffective, unable to respond to the deteriorating health status of the population, with a failure to engage in prevention particularly notable. ${ }^{89}$ In the hospital sector, even by 1990 about half of facilities lacked hot water, showers or bathrooms, while 15 percent were without any running water. ${ }^{90}$ The situation was especially bad in hospitals and other facilities in rural areas. Salaries of health professionals were about 30 percent lower than the average in the economy as a whole and the skill mix was increasingly out of line with health care elsewhere, with large numbers of low-paid and predominantly female doctors performing very basic tasks because there was nobody else to do them. Nursing was especially poorly developed, with the ratio of nurses to physicians about half of what it was in the west.

At a time when health care in the west was being changed fundamentally by developments in pharmaceuticals and technology, the USSR struggled to keep up. It was unable to develop a modern pharmaceutical industry, depending extensively

83 M. Ryan, J. Stephen, 'General practitioners and family doctors in the Russian Federation', Br J Gen Pract, 46 (1996), 487-9.

84 M. G. Field, Doctor and Patient in Soviet Russia (Cambridge, MA, Harvard University Press, 1957).

85 M. G. Field, 'The Soviet legacy: the past as prologue', in Health care in central Asia, McKee M., Healy J., Falkingham J. (Buckingham, Open University Press, 2002).

86 E. Mezentseva, N. Rimashevskaya, 'The Soviet country profile: Health of the USSR population in the 70s and 80s. - An approach to a comprehensive analysis', Social Science and Medicine, 31 (1990), 867-877.

87 M. Field, 'Postcomunist medicine: morbidity, mortality, and the deteriorating health situation', in The Social Legacy of Communism, ed. J. Millarand S. Wollchik. (New York \& Cambridge, UK, Woodrow Wilson Center Press and Cambridge University Press, 1994), pp. $178-195$.

88 D. Banerji, 'Reflections on the twenty-fifth anniversary of the Alma-Ata Declaration', Int J Health Serv, 33 (2003), 813-8.

89 J. B. Wyon, 'Deteriorating health in Russia- a place for community-based approaches (comment)', Am J Public Health, 86 (1996), 321-3.

90 B. R. Cassileth, Vlassov V. V., Chapman C. C., 'Health care, medical practice, and medical ethics in Russia today', Sociol Soc Research, 76 (1995), 81-84. 
on imports from its satellites in Eastern Europe and in the Indian sub-continent. Its problems also stemmed from the failure of Soviet science with its emphasis on ideology rather than empirical evidence. ${ }^{91}$ As a consequence, it used many ineffective physical treatments, involving radiation, electricity, light, and magnetism. These had the benefit of being an inexpensive means of appearing to do something useful. Technology that worked was more difficult to acquire, in part because of western regulations on transfer of technology that might have a military application.

It is now clear that, by the 1980s, the outcomes achieved by the Soviet health care system were lagging increasingly far behind the west, especially where modern health care was able to make a difference to mortality. ${ }^{92}$ For example, the MONICA study found that Russian outcomes following myocardial infarction were markedly worse than elsewhere. ${ }^{93}$ A study of mortality amenable to health care (deaths that should not occur in the presence of effective and timely care) found that, as such deaths steadily declined in western countries from the mid-1960s onwards, they remained resolutely high in Russia and other Soviet republics. In the late 1990s, mortality amenable to health care constituted about one fifth of the Russia-West gap in life expectancy of birth for males and about one quarter for females. ${ }^{94}$

Although, after 1991, some aspects of health care improved, as the opening of borders made it possible, at least in theory, to obtain modern drugs and technology, the economic crisis made them largely unaffordable. By 1994, health care expenditure was 10 percent lower than in $1990 .{ }^{95}$ Although the implementation of a new system of health care financing, based on health insurance, was relatively successful, about one in ten Russians remained without cover. ${ }^{96}$ However, reform of health care delivery proved more problematic. Although it was now possible to invest in labour-saving technologies and introduce innovative models of care, with patients remaining in the community, the government has been unwilling to

91 N. L. Krementosov, Stalinist Science (Princeton NJ, Princeton Univ. Press, 1997).

92 M. G. Field, 'Noble purpose, grand design, flawed execution, mixed results: Soviet socialized medicine after seventy years', Am J Public Health, 80 (1990), 144-5.

93 H. Tunstall-Pedoe, K. Kuulasmaa, M. Mahonen et al., 'Contribution of trends in survival and coronary-event rates to changes in coronary heart disease mortality: 10-year results from 37 MONICA Project populations', Lancet, 353 (1999), 1547-57.

94 E. M. Andreev, M. McKee, V. M. Shkolnikov, 'Health expectancy in the Russian Federation: a new perspective on the health divide in Europe', Bull WHO, 81 (2003), 778-788.

95 C. Davis, 'Economic transition, health production and medical system effectiveness in the former Soviet Union and Eastern Europe'. Paper prepared for the Project Meeting on Economic Shocks, Social Stress and the Demographic Impact, April 17-19 1997, Helsinki; J. Shapiro, 'Russian health care policy and Russian health', in Russian Political Development (London, Macmillan, 1997).

96 D. Balabanova, J. Falkingham, M. McKee, 'Winners and losers: The expansion of insurance coverage in Russia in the 1990s', Am J Publ Health, 93 (2003), 2124-2130. 
provide the necessary funds. ${ }^{97}$ As a consequence, the financial situation of health care facilities steadily worsened. This was happening at a time when the demands on the system were increasing ${ }^{98}$, with growing level of non-communicable diseases, a resurgence of previously controlled infections, in particular tuberculosis ${ }^{99}$, and the appearance of new ones, in particular HIV/AIDS. ${ }^{100}$ These new threats are characterised by an unprecedented level of complexity. In the past, when health care had relatively little to offer, the care provided could be basic yet adequate, in comparison with that available elsewhere. Chronic non-communicable diseases, such as diabetes, which affects many different body systems and thus requires the combined efforts of the array of narrow medical specialists that characterise the Russian system, provide a new challenge. So do the complex communicable diseases, exemplified by HIV but also including multi-drug resistant tuberculosis. It is not clear that the Russian system, as presently configured, is in a position to respond to these threats. ${ }^{101}$

One can also look at the Russian medical care situation in the 1990s from a comparative perspective in the context of recent experiences of other transitional countries in Eastern Europe. In particular, detailed analyses by Rychtarikova ${ }^{102}$ of components of mortality decrease in the Czech Republic together with changes in health-related behaviours and in medical care, clearly suggest a very important (if not decisive) part played by medical care. The overall mortality decrease was largely due to reduction of cardiovascular death at middle and old ages. It coincided with substantial increase in the health budget from 5 percent in 1990 to 7.4 percent in 2001 and dramatic increases in use of new beta-blockers, calcium channel blockers, lipid lowering drugs and other modern pharmaceutical preparations. There was also a striking growth in invasive cardiac procedures, such as coronary artery by-pass grafts, valve replacements and angioplasties. The author argues that, over this period, lifestyle factors have not changed so much. Smoking and alcohol consumption have slightly increased, while consumption of vegetable oil has partly replaced animal fat. The author concluded that technical progress in health care is

97 Human Development Report 1995. Russian Federation. (Oxford, Oxford Univ. Press, 1995).

98 T. H. Tulchinsky, E. A. Varavikova, 'Addressing the epidemiological transition in the former Soviet Union: strategies for health system and public health reform in Russia', Am J Publ Health, 86 (1996), 220-238.

99 R. Coker, 'Control of tuberculosis in Russia', Lancet, 358 (2001), 434-5.

100 J. A. Kelly, Y. A. Amirkhanian, 'The newest epidemic: a review of HIV/AIDS in Central and Eastern Europe', Int J STD AIDS, 14 (2003), 361-71.

101 R. J. Coker, R. A. Atun, M. McKee, 'Health care system frailties and public health control of communicable disease on the European Union's new eastern border', Lancet, 363 (2004), 1389-92.

102 J. Rychtarikova, 'The case of Czech Republic. Determinants of the recent favourable turnover in mortality', Demographic Research, 2004. Special collection 2, Article 5. 
an important cause of the recent mortality decline in the Czech Republic, although this analysis may underestimate the consequences of dietary change.

It seems likely that the situation is similar in other countries, which experienced large mortality downturns in the 1990s such as Hungary, Poland, and Slovenia. In each, mortality reduction was especially significant at ages over 65 and from cardiovascular diseases: The decline ranged from about 20 percent in Hungary to about 40 percent in Slovenia. ${ }^{103}$

Thus, successful Eastern European countries have managed to increase their health care resources and introduce efficient methods of treatment and prevention of cardiovascular disease. This provides a sharp contrast with Russia. In the Czech Republic, Hungary, Poland and Slovenia, health expenditures in 2001 as a percentage of Gross Domestic Product were 7-9 percent vs. only 2.9 percent in Russia. $^{104}$

In summary, the Russian health care system, despite its many historical achievements, has failed to keep pace with developments over the past four decades. It was largely due to unwillingness or inability of the government to deliver sufficient resources. It now requires adequate funding sustained over a long period, linked to fundamental reform, if it is to be able to respond to the many challenges it now faces.

\section{Russian Society, the Psychosocial Responses to Communism and the Transition}

More than seventy years of communist rule did not prepare the Russian population well for the transition they experienced in the 1990s. The Soviet ideology placed the interests of the state above those of the individual ${ }^{105}$, a policy whose terrible consequences were most clearly manifest in the phenomenon of the Gulag. ${ }^{106}$ People were taught to sacrifice their lives to build communism and to compete with the West; the value of individual life and health was low.

In exchange, the paternalistic state promised to take care of people from birth to death by providing cheap food, apartments, and transport, with free health care and education. The quality was not high but at least they were universally accessible (although there was always a shortage of housing, this was ameliorated to some

103 HFA-MDB. Mortality by leading causes of death. Supplement to European Health for All Database. WHO Office for Europe, 2003. http://www.who.dk/hfadb.

104 HFA. European Health for All Database. WHO Office for Europe, 2003. http://www.who.dk/hfadb.

105 Shkolnikov and Meslé, (1996).

106 A. Applebaum, Gulag: A History of the Soviet Concentration Camps (London, Allen lane, 2003). 
extent by a strict system of residence permits). This situation engendered a feeling of passivity, with most people believing that the state would help should a disaster, such as a serious health problem, arise. One consequence was the creation of a culture in which it was felt that there was little that individuals could do to protect their own health. ${ }^{107}$

By the 1960s and the 1970s it was becoming increasingly clear that the aspirations of the communist ideology were unrealistic, a view encouraged by events in Hungary and Czechoslovakia, where Eastern European "friends and allies" of the USSR were less than happy with "real socialism". As chinks appeared in the "iron curtain" in the 1960s and 1970s, Russians began to see the gap opening up between their living standards and those in the west. Unpublished surveys revealed a growing popular disillusionment with the communist system ${ }^{108}$ and an erosion of social norms and values. ${ }^{109}$ This disillusionment was exacerbated by the increasing evidence of corruption, reaching to the heart of the ruling elite. As a consequence, people were becoming increasingly alienated from the state and from official institutions.

Individuals and communities faced numerous constraints. There was no legitimate scope to increase income and little on which to spend what they had. Official organisations, such as the communist youth movement, or pioneers, took the place of the civil society organisations that developed spontaneously in the west. In other words, there was little scope for self-realisation. This, coupled with the "effort-reward" imbalance ${ }^{110}$ that many people experienced at work, led to psychological stress. Young men with little social support, in particular the unmarried, were most vulnerable. ${ }^{11}$

In these circumstances, it was inevitable that a sudden shock to the system would be traumatic. When this occurred as the Soviet Union broke apart in 1991 and major economic reform began in 1992, the already upward trajectory of mortality accelerated. The population was unable to cope with the new socio-economic realities. ${ }^{112}$ Over the following three years, the speed of change increased, although

107 I. Nazarova, 'Self-rated health and occupational conditions in Russia', Soc Sci Med, 51 (2000), 1375-1385.

108 R. Service, A history of twentieth century Russia (London, Allen Lane, 1997).

109 P. Makara, 'Policy implications of differential health status in Eastern Europe: the case of Hungary', Soc Sci Med, 39 (1994), 1295-1302.

110 J. Siegrist, 'Place, social exchange and health: proposed sociological framework', Soc Sci Med, 51 (2000), 1283-1293.

111 P. Watson, 'Explaining rising mortality among men in Eastern Europe', Soc Sci Med, 41 (1995), 923-934; P. Hajdu, M. McKee, F. Bojan, 'Changes in premature mortality differentials by marital status in Hungary and in England and Wales', Eur J Publ Health, 5 (1995), 259-64.

112 J. Shapiro, 'The Russian mortality crisis and its causes', in Economic Reform at Risk, Ed. A.Aslund (London, 1995), pp. 149-178. 
the transition was uneven and those in the areas experiencing the most rapid transition fared worst $^{113}$, with large increases in mortality, especially from cardiovascular diseases and from injuries and violence. ${ }^{114}$

A weakening of many state institutions, with their accompanying systems of control, contributed to growing uncertainty. There was widespread erosion of social norms, cohesion ${ }^{115}$, and of law and order. One manifestation was a marked increase in the murder rate, with an increasingly diverse range of people involved, both as victims and perpetrators. ${ }^{116}$ Another was the growth in use of narcotics, as alienated young people sought relief from the hopelessness all around them.

By the end of the 1990s, therefore, Russia was becoming an increasingly fractured society, with a few people at the top achieving enormous wealth while large numbers fell to the bottom, marginalised from mainstream society.

Although the psychosocial stress explanation is plausible in light of the timing of mortality upturns in 1992 (after the beginning of reforms) and in 1999 (after the 1998 economic crisis) and is supported by the arguments presented so far, direct evidence linking psychological stress with health and mortality is still very limited. The study by Bobak et al. ${ }^{117}$ found a strong association of perceived control over one's life with low self-rated health and poor physical functioning in a nationally representative sample of the Russian population. It is not clear, however, to what extent self-rated health predicts largely violent or sudden mortality among men at working ages, which was a core part of mortality increase in the early 1990s. Another study in Novosibirsk revealed a strong association between the effortreward ratio and depression ${ }^{118}$. A study in Taganrog ${ }^{119}$ revealed an association between heavy alcohol consumption in men and economic pressures on families and family conflicts. It seems, however, that this relationship could also work in a reverse direction. The Udmurt study ${ }^{120}$ showed associations between premature deaths of men at ages from 20 to 55 and several measures of psychological stress.

113 G. A. Cornia, R. Paniccià, 'The transition mortality crisis: evidence, interpretation and policy responses', in The mortality crisis in transitional economies, Ed. by G. A. Cornia, R. Paniccià (Oxford University Press, 2000), pp. 3-37.

114 P. Walberg, M. McKee, V. Shkolnikov, L. Chenet, D. Leon, 'Economic change, crime and Russian mortality crisis: a regional analysis', BMJ, 317 (1998), 312-318.

115 M. Bobak, H. Pikhart, C. Hertzman, R. Rose, M. Marmot, 'Socioeconomic factors, material inequalities, and perceived control in self-rated health: cross-sectional data from seven post-communist countries', Soc Sci Med, 51 (2000), 1343-1350; R. Rose, 'How much does social capital add to individual health? A survey study of Russians', Soc Sci Med, 51 (2000), 1421-1435.

116 Chervyakov et al., (2002).

117 Bobak et al., (1998)

118 Pikhart et al., (2004).

119 Carlson and Vågerö, (1998).

120 Shkolnikov and Chervyakov, (2000). 
Unfortunately, the information on stress in the deceased was collected from proxy informants and could be biased.

Finally, at the physiological level, the LiviCordia study, which compared Vilnius (Lithuania) and Linköping (Sweden) ${ }^{121}$ sought to explain the four-fold difference in mortality from coronary heart disease between 50-year old men from Lithuania and Sweden. It found elevated levels of psychosocial stress, job strain, social isolation, poor coping skills, low self-esteem, exhaustion, and depression along with attenuated cortisol responses to stress in Vilnius.

\section{Summary and Conclusion}

Amartya Sen, winner of the 1998 Nobel Prize for economics, in an influential 1995 lecture, considers mortality as a key measure of the success or failure of a country's development. ${ }^{122}$ This inspiring idea is grounded in the fact that mortality is a reflection of society's ability to transform its economic resources into the most important public good, its nation's health. Simple indicators of mortality can often say more about the level and direction of a society's development than complex macro-economic indicators. Following this line one can conclude that Russian socio-economic development in the $20^{\text {th }}$ century was generally poor. In the first half of the $20^{\text {th }}$ century, Russian mortality was very high because of the traditional causes, including very high infant mortality due to infectious disease. Between the October revolution of 1917 and the death of Stalin in 1952, the Russian population faced enormous demographic disasters caused by the two world wars, famines, and Stalin's political repressions. This legacy did not prevent Russia from making a spectacular progress in the 1950 s, with a radical reduction in mortality among children following universal access to primary health care, immunisation, and antibiotics.

However, by the mid-1960s mortality began to increase and this trend has continued until now with only two short interruptions in the second halves of the 1980s and the 1990s. This has been the first example of sustained mortality reversal in the $20^{\text {th }}$ century. Mortality began to increase at the very moment when the Soviet Union was at the height of its economic and military power, even at a time when the USSR was enjoying economic growth, indicating a fundamentally negative process at the core of the Soviet society.

121 Kristenson and Kucinskiene, (2002).

122 A. Sen, 'Mortality as an Indicator of Economic Success and Failure'. Inaugural Lecture. Instituto degli Innocenti, 1995. 
After the fall of communism and the disintegration of the Soviet Union, the mortality increase in Russia has become steeper. This differentiates it from the former communist countries of Eastern Europe, which have experienced a substantial reduction in mortality in the 1990s. The worsening mortality situation in Russia once again documents a failure of Russian socio-economic development in this new stage of its political history.

The present study provides a systematic description of adverse mortality trends and summarizes the scientific evidence on the nature of the health crisis in Russia available so far. We begin by looking at the timing and the age- and cause-of-death patterns within the overall mortality increase. Mortality fell briefly during Gorbachev's anti-alcohol campaign and then began to increase sharply in 1992, just after collapse of the Soviet Union and the subsequent painful socio-economic transformation, with a further deterioration after the economic crisis of 1998.

The underlying excess mortality in Russia and its sharp increase in the 1990s were very much concentrated among men of working age with low level of education, especially those who were not married. Mortality among highly educated Russians is about the average level of western populations. However, even mortality in this most advanced section of the Russian population is substantially higher than in their western counterparts who have high education. Among men the adverse situation is mostly driven by high mortality from circulatory diseases at middle and old ages and from external and alcohol-related causes of death at young adult and middle ages. Excess mortality among women is mostly related to higher mortality at ages over 60 from circulatory diseases. In both men and women, there is a heavy burden of reported ill-health at old ages.

Although conventional risk factors such as smoking and elevated blood pressure are relatively frequent in the Russian population, they can explain only a part of the excess mortality in Russia compared to the West or of the mortality differentials across groups within the Russian population. We thus considered a number of explanations that are supported by evidence from the work of ourselves and others on mortality and health in Russia during the last ten years.

While some patterns of the Russian mortality such as changes in mortality from lung and stomach cancers can be linked to events in the past, these do not play a principal part in the recent increases in Russian mortality.

The consequences of smoking for mortality are very similar to those observed in other countries. However, the high prevalence of smoking among Russian men suggests a high population attributable risk from this factor, with smoking elevating mortality from ischaemic heart disease and cancers of the lung, aerodigestive tract, and some other sites. Although smoking in Russia increased in the 1990s, the mortality fluctuations of the late 1980s-1990s are unrelated to current patterns of smoking. 
The impact of alcohol on mortality and especially on these fluctuations between 1985 and 1995 appears to be much stronger than expected. This can be attributed to the episodic pattern of drinking, involving consumption of large amounts of vodka, resulting not only in excess deaths from alcohol-related and external causes, but also in large numbers of premature deaths from cardiovascular causes.

The role of nutrition is less clear. It seems that a high intake of fatty foods combined with low physical activity is likely to be contributing to the growth of obesity and subsequent ill-health, especially among Russian women. It also seems likely that a low intake of micronutrients, in particular those derived from fresh fruit and vegetables, is contributing to the high rate of cardiovascular disease and of some cancers.

The inadequacies of the Russia health care system are increasingly recognized. Its past strengths are no longer adequate for the challenge it now faces. It is clearly failing to deal with a rising tide of complex chronic disease. The situation may be getting worse during the early 1990s with an increasing gap between needs and funding, as well as a failure to adopt new technologies and working methods for treatment and prevention. According to some estimates, one fifth to one quarter of the Russia-West gap in life expectancy at birth could be attributed to deaths from conditions amenable to health care. These signs of decline are especially worrying in the face of emerging threats of HIV/AIDS and multi-drug resistant tuberculosis.

Finally, there is a fundamental question about some more general societal reasons why the health crisis in Russia has been so deep and persistent. Obviously, the often chaotic political and socio-economic transition of the 1990s created high levels of psychosocial stress, resulting in many premature deaths. The psychosocial stress affects men more than women, as the latter have, traditionally, found support from their roles as carers for families. This stress can be a direct cause of ill-health and even death but, more often, its effects are indirect, leading to heavy drinking and other health damaging behaviour as a way to cope with it and so to "escape" from the grim reality that is life for many people in Russia today.

Yet the health crisis began much earlier than the 1990s. How can one explain, for example, the persistence of adverse health behaviours among Russian men? We argue that the core of the problem can be related to the very nature of the communist and post-communist societies in Russia. Both the oppressive communist regime and the emerging "hour-glass" post-communist society have given a low priority to the health of the individual. There has been a continuous neglect of social and health care needs when deciding resource allocation, reducing the prospects of the worst-off groups in the population from achieving adequate living standards or access to effective services, including health care.

This society has failed to develop a legal system that offers equal chances to everyone. This in turn restricts life chances and leads to a large-scale effort-reward 
imbalance, especially among people whose initial situation is weakest, who are then unable to cope with rapidly changing economic conditions.

Vladimir M. Shkolnikov is Head of the Laboratory for Demographic Data at Max Planck Institute for Demographic Research, D-18057 Konrad-Zuse-Str, 1, Rostock, Germany. Evgueni M. Andreev is Head of Laboratory for Analysis and Prognosis of Mortality at the Centre of Demograpgy and Human Ecology, Moscow Nakhimovski prospect, 47 Moscow, Russia. David A. Leon is Professor of Epidemiology at London School of Hygiene and Tropical Medicine, Keppel St, London WC1E 7HT, United Kingdom. Martin McKee is Professor of the European Public Health at London School of Hygiene and Tropical Medicine. France Meslé is Directeur de recherche at INED (Institut national d'études démographiques), 133 boulevard Davout 75980 Paris cedex 20, France. Jacques Vallin is Directeur de recherche at INED, Paris. 


\section{References}

Anderson B., Silver B.,'Patterns of the cohort mortality in the Soviet Population', Pop Dev Rev, 15 (1989), 471-501.

Andreev E. M., McKee M, Shkolnikov V. M., 'Health expectancy in the Russian Federation: a new perspective on the health divide in Europe', Bull WHO, 81 (2003), 778-788.

Andreev E. M., Nolte E. Shkolnikov VM, Varavikova E, McKee M., 'The evolving pattern of avoidable mortality in Russia', Int J Epidemiol, 32 (2003), 437-446.

Aneshensel C. S., Rutter C. M., Lachenbruch P. A., 'Social structure, stress and mental health: competing conceptual and analytical models', Am Sociol Rev, 56 (1991), 166-78.

Applebaum A., Gulag: A History of the Soviet Concentration Camps (London, Allen lane, 2003).

Avdeev A., Blum A., Zakharov S., Andreev E., 'The reactions of a heterogeneous population to pertubation. An interpretative model of mortality trends in Russia', Population: An English Selection, 10(2) (1998), 267- 302.

Averina M., Nilssen O., Brenn T., Brox J., Kalinin A. G., Arkhipovsky V. L., 'High cardiovascular mortality in Russia cannot be explained by the classical risk factors. The Arkhangelsk Study 2000', Eur J Epidemiol, 18 (2003), 871-8.

Balabanova D., Falkingham J., McKee M., 'Winners and losers: The expansion of insurance coverage in Russia in the 1990s', Am J Publ Health, 93 (2003), 21242130 .

Banerji D., 'Reflections on the twenty-fifth anniversary of the Alma-Ata Declaration', Int J Health Serv, 33 (2003), 813-8.

Bobak M., Pikhart H., Hertzman C., Rose R., Marmot M., 'Socioeconomic factors, material inequalities, and perceived control in self-rated health: cross-sectional data from seven post-communist countries', Soc Sci Med, 51 (2000), 13431350 .

Britton A., McKee M., 'The relationship between alcohol and cardiovascular disease in Eastern Europe: explaining the paradox', J Epidemiol Comm Health, 54 (2000), 328-332.

Bobak M., McKee M., Rose R., Marmot M., 'Alcohol consumption in a national sample of the Russian population', Addiction, 94 (1999), 857-66.

Carlson P., 'Self-perceived health in East and West Europe: Another European health divide', Soc Sci Med, 46 (1998), 1355-1366.

Carlson P., Vägerö D., 'The social pattern of heavy drinking in Russia during transition: evidence from Taganrog 1993', Eur J Publ Health, 8 (1998), 280-285. 
Caselli G., Meslé F., Vallin J., 'Epidemiologic transition theory reversals', Genus, 58(1) (2002), 9-52.

Cassileth B. R., Vlassov V. V., Chapman C. C., 'Health care, medical practice, and medical ethics in Russia today', Sociol Soc Research, 76 (1995), 81-84.

Chen L., Wittgenstein F., McKeon E., 'The upsurge of mortality in Russia: causes and policy implication', Pop Dev Rev, 22 (1996), 517-530.

Chenet L., Leon D., McKee M., Vassin S., 'Deaths from alcohol and violence in Moscow: socio-economic determinants', Eur J Pop, 14 (1998), 19-37.

Chenet L., McKee M., Leon D., Shkolnikov V., Vassin S., 'Alcohol and cardiovascular mortality in Moscow, new evidence of a causal association', $J$ Epidemiol Comm Health, 52 (1998), 772-74.

Chekhov A. P., The island: a journey to Sakhalin (London, Pimlico, 1987).

Chervyakov V. V., Shkolnikov V. M., Pridemore W. A., McKee M., 'The changing nature of murder in Russia', Soc Sci Med, 55 (2002), 1713-1724.

Cockerham W. C., Health and Social Change in Russia and Eastern Europe (Routledge, New York, 1999).

Coker R., 'Control of tuberculosis in Russia', Lancet, 358 (2001), 434-5.

Coker R. J., Atun R. A., McKee M., 'Health care system frailties and public health control of communicable disease on the European Union's new eastern border', Lancet, 363 (2004), 1389-92.

Cornia G. A., Paniccià R., 'The transition mortality crisis: evidence, interpretation and policy responses', in The mortality crisis in transitional economies, Ed. by G. A. Cornia, R. Paniccià (Oxford University Press, 2000), pp. 3-37.

Davey Smith G., Gunell D., Ben-Shlomo Y., 'Life-course approaches to socioeconomic differentials in cause-specific motality', in Poverty, Inequality, and Health, ed. D. A. Leon, G. Walt. (Oxford, Oxford University Press, 2001), pp. 88-124.

Davis C., The economics of the Soviet health system (Cambridge, Cambridge University Press, 1979).

Davis C., 'Economic transition, health production and medical system effectiveness in the former Soviet Union and Eastern Europe'. Paper prepared for the Project Meeting on Economic Shocks, Social Stress and the Demographic Impact, April 17-19 1997, Helsinki.

Deev A., Shkolnikov V., 'Neodnorodnost' smertnosti: amaliz individualnikh dannyh', ['Heterogeneity of mortality: analysis of individual-level data'] in Neravenstvo $i$ Smertnost $v$ Rossii [Inequality and Mortality in Russia], Eds., Shkolnikov V., Andreev E., Maleva T. (Moscow, Carnegie Center, 2000).

Demeny P., 'Investment allocation and population growth', Demography, 2 (1965), 203-232.

Dennis B. H., Zhukovsky G. S., Shestov D. B., Davis C. E., et al., 'The association of education with coronary heart disease mortality in the USSR Lipid 
Research Clinics Study', Int. J. Epidemiol 22 (1993), 420-427.

Domanski H., 'Distribution of incomes in Eastern Europe', International Journal of Comp Sociol XXXVIII (1997), 249-270.

Evans C., Chalmers J., Capewell S., Redpath A., Finlayson A., Boyd J., Pell J., McMurray J., Macintyre K., Graham L., "II don't like Mondays” day of the week of coronary heart disease deaths in Scotland: study of routinely collected data', BMJ, 320 (2000), 218-219.

Field M. G., Doctor and Patient in Soviet Russia (Cambridge, MA, Harvard University Press, 1957).

Field M. G., 'Noble purpose, grand design, flawed execution, mixed results: Soviet socialized medicine after seventy years', Am J Public Health, 80 (1990), 144-5.

Field M., 'Postcomunist medicine: morbidity, mortality, and the deteriorating health situation', in The Social Legacy of Communism, ed. J.Millarand S. Wollchik. (New York \& Cambridge, UK, Woodrow Wilson Center Press and Cambridge University Press, 1994), pp. 178-195.

Field M., 'The health crisis in the former Soviet Union: a report from the 'post-war' zone', Soc Sci Med, 41 (1995), 23-34.

Field M. G., 'The Soviet legacy: the past as prologue', in Health care in central Asia, McKee M., Healy J., Falkingham J. (Buckingham, Open University Press, 2002).

Gilmore A., McKee M., 'Moving east: how the transnational tobacco companies gained entry to the emerging markets of the former Soviet Union. Part I: Establishing cigarette imports', Tobacco Control, 13 (2004), 143-150.

Gilmore A., McKee M., 'Moving east: how the transnational tobacco companies gained entry to the emerging markets of the former Soviet Union. Part II: an overview of priorities and tactics used to establish a manufacturing presence', Tobacco Control, 151-160.

Gilmore A. B., Pomerleau J., McKee M., Rose R., Haerpfer C. W., Rotman D., Tumanov S., 'Prevalence of smoking in eight countries of the former Soviet Union: results from the Living conditions, Lifestyles and Health study', Am J Publ Health (in press).

Ginter E., 'Cardiovascular risk factors in the former communist countries. Analysis of 40 European MONICA populations', Eur J Epidemiol, 11 (1995), 199-205.

Hajdu P., McKee M., Bojan F., 'Changes in premature mortality differentials by marital status in Hungary and in England and Wales', Eur J Publ Health, 5 (1995), 259-64.

Haynes M., Husan R., A century of state murder: death and policy in twentieth century Russia (London, Pluto Press, 2003).

HFA. European Health for All Database. WHO Office for Europe, 2003. http://www.who.dk/hfadb.

HFA-MDB. Mortality by leading causes of death. Supplement to European Health 
for All Database. WHO Office for Europe, 2003. http://www.who.dk/hfadb. Human Development Report 1995. Russian Federation. (Oxford, Oxford Univ. Press, 1995).

Human Mortality Database, 2004. Department of Demography at the University of California at Berkeley and Max Planck Institute of Demographic Research. Available at www.mortality.org.

Kannisto V., 'Measuring the compression of mortality', Demographic Research, 2000, volume 3, article 6, www.demographic-research.org.

Kelly J. A., Amirkhanian Y. A., 'The newest epidemic: a review of HIV/AIDS in Central and Eastern Europe', Int J STD AIDS, 14 (2003), 361-71.

Kisseleva N. G., 'Nutrition'. Annex 7.3. in Inception Report: Preventive Health Care. Tacis-project, Annexes, Volume II. (Moscow, 1998).

Kochanek K. D., Maurer J. D., Rosenberg H. M., 'Why did black life expectancy decline from 1984 through 1989 in the United States?', Am J Public Health, 84 (1994), 938-44.

Krementosov N. L ., Stalinist Science (Princeton NJ, Princeton Univ. Press, 1997).

Kristenson M., Kucinskiene Z., 'Possible causes of differences in coronary heart disease mortality between Lithuania and Sweden: the LiVicordia Study', in Heart Disease: Environment, Stress, and Gender, ed. by G.Weidner, M.Kopp, M.Kristenson. (Amsterdam, IOS Press, 2002), pp. 328-340.

Krug P., 'The Debate over the Delivery of Health Care in Rural Russia: The Moscow Zemstvo, 1864-1878', Bull History Med, 50 (1976), 226-241.

Leon D. A., 'Common threads: underlying components of inequalities in mortality between and within countries', in Poverty, Inequality, and Health, ed. D. A. Leon, G. Walt (Oxford, Oxford University Press, 2001), pp. 58-87.

Leon D. A., Chenet L., Shkolnikov V., Zakharov S. et al., 'Huge variation in Russian mortality rates 1984-1994. Artefact, alcohol or what?', Lancet, 350 (1997), 383-388.

Lock K,. Pomerleau J., Causer L., McKee M., 'Low fruit and vegetable consumption', in Comparative Quantification of Health Risks: Global and Regional Burden of Disease Due to Selected Major Risk Factors, eds. Ezzati M, Lopez AD, Rodgers A, Murray CJL. (Geneva, WHO) (in press).

Makara P., 'Policy implications of differential health status in Eastern Europe: the case of Hungary', Soc Sci Med, 39 (1994), 1295-1302.

Mäkelä P., Valkonen T., Poikolainen K., 'Estimated numbers of deaths from coronary heart disease "caused" and "prevented" by alcohol: an example from Finland', J Studies Alcohol, 58 (1997), 455-463.

Martikainen P., Aromaa A., Heliovaara M., Klaukka T., Knekt P., Maatela J., Lahelma E., 'Reliability of perceived health by sex and age', Soc Sci Med, 48 (1999), 1117-22.

Manor O., Matthews S., Power C., 'Self-rated health and limiting longstanding 
illness: inter-relationships with morbidity in early adulthood', Int J Epidemiol, 30 (2001), 600-7.

McKee M., Shkolnikov V., 'Understanding the toll of premature death among men in eastern Europe', BMJ, 323 (2001), 1051-5.

McKee M., Shkolnikov V., Leon D. A., 'Alcohol is implicated in the fluctuations in cardiovascular disease in Russia since the 1980s', Ann Epidemiology, 11 (2001), $1-6$.

McKee M., 'Alcohol in Russia', Alcohol Alcoholism, 34 (1999), 824-829.

McKee M., Britton A., 'The positive relationship between alcohol and heart disease in eastern Europe: potential physiological mechanisms', J.R.Soc.Med., 91 (1998), 402-7.

McKee M., Bobak M., Rose R., Shkolnikov V., Chenet L., Leon D., 'Patterns of smoking in Russia', Tobacco Control, 7 (1998), 22-26.

McMichael A. J., McKee M., Shkolnikov V., Valkonen V., 'Mortality trends and setbacks: global convergence or divergence?', Lancet, 363 (2004), 1155-9.

Meslé, F., 'Mortality in Central and Eastern Europe: long-term trends and recent upturns', Demographic Research, 2004, Special Collection 2, Article 3. www.demographic-research.org

Meslé, F., Shkolnikov, V. M., Hertrich, V., Vallin, J., Tendences recentes de la mortalite par cause en Russie 1965-1994. Serie: Donées Statistiques, 2, (INED, Paris, 1996), 140p.

Meslé F., Vallin J., 'Évolution et variations géographiques de la surmortalité masculine Du paradoxe français à la logique russe', Population, 53(4-5) (1998), 1079-1102.

Meslé, F., Vallin, J., Hertrich, V., Andreev, E. M., Shkolnikov, V. M., 'Causes of death in Russia: assessing trends since the 1950s', in Population of Central and Eastern Europe. Challenges and opportunities, Ed by Irena E. Kotowska and Janina Jozwiak (Statistical Publishing Establishment, Warsaw, 2003), pp. 389-414.

Meslé F., Vallin J., Shkolnikov V., 'Reversal of mortality decline: the case of contemporary Russia', World Health Stat Q, 51 (2000), 191-206.

Meslé F., Shkolnikov V. M., Vallin J., 'Brusque montée des morts violentes en Russie', Population, 3 (1994), 780-790.

Mezentseva E., Rimashevskaya N., 'The Soviet country profile: Health of the USSR population in the $70 \mathrm{~s}$ and $80 \mathrm{~s}$. - An approach to a comprehensive analysis', Social Science and Medicine, 31 (1990), 867-877.

Murray C. J. L., Lopez A. D. (eds)., The global burden of disease (Boston MA, WHO, Harvard School of Public Health, World Bank, 1996), pp 307-8.

Nazarova I., 'Self-rated health and occupational conditions in Russia', Soc Sci Med, 51 (2000), 1375-1385.

Nemtsov A. V., 'Alcohol-related human losses in Russia in the 1980s and 1990s', Addiction, 97 (2002), 1413-1425. 
Palosuo H., Zhuravleva I., Uutela A., Lakomova N., Shilova L., Perecived Health, Health-Related Habits and Attitudes in Helsinki and Moscow: A Comparative Study of Adult Populations in 1991. A10/1995. (Helsinki, National Public Health Institute, 1995).

Paniccià R., 'Transition, impoverishment, and mortality: how large an impact?', in The mortality crisis in transitional economies, Ed. by G.A. Cornia, R.Paniccià. (Oxford, Oxford University Press, 2000), pp. 105-126.

Pirogov G., Pronin S., 'The Russian case: social policy concerns', in Poverty in Transition and Transition and Transition in Poverty. Recent Developments in Hungary, Bulgaria, Romania, Georgia, Russia and Mongolia, Ed. Atal Y (New York, Oxford \& Paris, UNESCO, Publishing \& Bergham Books, 1999).

Plavinsky S. L., Plavinskaya S. I., Klimov A. N., 'Social factors and increase in mortality in Russia in the 1990s: prospective cohort study', BMJ, 326 (2003), $1240-1242$.

Popkin B. M, Zohoori N., Kohlmeier L., Baturin A., Martinchik A., Deev A., 'Nutritional risk factors in the former Soviet Union', in Premature Death in the New Independent States, Eds. Bobadilla, J.-L., Costello, C. and Mitchell, F. (Washington D. C., National Academy Press, 1997), pp. 314-334.

Pridemore W. A., 'Vodka and violence: alcohol consumption and homicide rates in Russia', Am J Public Health, 92 (2002), 1921-30.

Prokhorov A., 'Cigarette smoking and priorities for tobacco control in the Newly Independent States', in Premature Death in the New Independent States, eds. J.L. Bobadilla, C. A.Costello, and Faith Mitchell (National Academy Press, 1997), pp. 275-286.

Prokhorov B. B., Andreev E. M., Sakevich V. I., 'Zdorovye', ['Health'] in Naseleniye Rossii 2001. Devyatiy Ezhegodniy Demografitcheskiy Doklad, [Population of Russia 2001. The Ninth Annual Demographic Report] ed. by. A. G.Vishnevski (INP RAN, Moscow, 2002), pp. 70-98.

RLMS. Russia Longitudinal Monitoring Survey. http://www.cpc.unc.edu/rlms/.

Robine J-M, Mathers C. D., Bone M. R., Romieu I., eds., Calculation of health expectancies: harmonization, consensus achieved and future perspectives (London, John Libbey Eurotex, 1993).

Robine J-M., Romieu I., Cambois E., 'Health expectancy indicators', Bulletin of the WHO, 77(2), pp. 181-185.

Rose R., 'How much does social capital add to individual health? A survey study of Russians', Soc Sci Med, 51 (2000), 1421-1435.

Ryan M., Stephen J., 'General practitioners and family doctors in the Russian Federation', Br J Gen Pract, 46 (1996), 487-9.

Rychtarikova J., 'The case of Czech Republic. Determinants of the recent favourable turnover in mortality', Demographic Research, 2004. Special collection 2, Article 5. 
Sadana R., Mathers C. D., Lopez A. D., Murray C. J. L., Moesgaard-Iburg K., 'Comparative analysis of more than 50 household surveys of health status', in Summary Measures of Population Health: Concepts, Ethics, Measurement and Applications, editors Murray C.J.L., Salomon J.A., Mathers C.D., Lopez A.D. (Geneva, WHO, 2002), pp. 369-386.

Seebag-Montefiore S., Stalin. The court of the red Tsar (London, Weidenfeld \& Nicholson, 2003).

Sen A., 'Mortality as an Indicator of Economic Success and Failure'. Inaugural Lecture. Instituto degli Innocenti, 1995.

Service R., A history of twentieth century Russia (London, Allen Lane, 1997).

Shapiro J., 'Russian health care policy and Russian health', in Russian Political Development (London, Macmillan, 1997).

Shapiro J., 'The Russian mortality crisis and its causes', in Economic Reform at Risk, Ed. A. Aslund (London, 1995), pp. 149-178.

Shestov D. B., Deev A. D., Klimov A. N., Davis C. E., Tyroler H. A., 'Increased risk of coronary heart disease death in men with low total and low-density Lipoprotein Cholesterol in the Russian lipid research clinics prevalence followup study', Circulation, 88 (1993), 846-853.

Shkolnikov V. M., Chervyakov V. V., Leon D. A., McKee M., 'Russian mortality beyond vital statistics. Effects of social status and behaviours on deaths from circulatory disease and external causes - a case-control study of men aged 20$55^{\prime}$.

Shkolnikov V. M., Cornia G. A., Leon D. A., Meslé F., 'Causes of the Russian Mortality Crisis: Evidence and Interpretations', World Development, 26 (1998), 1995-2011.

Shkolnikov V. M., Meslé F., 'Russian epidemiological crisis as mirrored by mortality trends', in Russia's Demographic “Crisis", ed. J DaVanzo (Santa Monica, CA, RAND, 1996), pp.113-162.

Shkolnikov V. M., Andreev E. M., 'Differences by education and character of labor', in Neravenstvo i smertnost v Rossii, [Inequality and Mortality in Russia] ed. Shkolnikov V. M., Andreev E. M., Maleva T. (Signal, Moscow, 2000), pp. 34-43.

Shkolnikov, V. M., Andreev, E. M., Begun, A. Z., 'Gini coefficient as a life table function: computation from discrete data, decomposition of differences and empirical examples', Demographic Research. Vol. 8, article 11, 2003, www.demographic-research.org.

Shkolnikov, V. M., Chervyakov, V.V. Ed., Policies for the Control of the Transition's Mortality Crisis in Russia. Project No RUS/98/G51, UNDP/Russia, Moscow, 2000, 159 p. (In Russian and English languages).

Shkolnikov V. , Leon D., Adamets S., Andreev E., Deev A., 'Educational level and adult mortality in Russia: an analysis of routine data 1979 to 1994', Soc Sci Med, 47 (1998), 357-369. 
Shkolnikov V. M., Deev A. D., Kravdal Ø., Valkonen T., 'Educational differentials in male mortality in Russia and northern Europe. A comparison of an epidemiological cohort from Moscow and St. Petersburg with the male populations of Helsinki and Oslo', Demographic Research, 2003; 10: Article 1, www.demographic-research.org/

Shkolnikov V. M., Rozenfeld B. A., 'Zdravoohraneniye i Krizis Obschestvennogo Zdorovya v Rossii', ['The medical care and health crisis in Russia'] Komputerniye Tekhnologii v Medicine, 1 (1997), 18-23.

Shkolnikov V., McKee M., Leon D., Chenet L., 'Why is the death rate from lung cancer falling in the Russian Federation?', Eur J Epidemiol, 15 (1999), 203206.

Shkolnikov, V. M., McKee, M., Vallin, J., Aksel, E., Leon, D., Chenet, L., Meslé, F., 'Cancer mortality in Russia and Ukraine: validity, competing risks, and cohort effects', International Journal of Epidemiology, 28, (1999), pp. 19-29.

Shkolnikov V., Cornia G. A., 'Population crisis and rising mortality in transitional Russia', in The transition's mortality crisis, eds. Cornia G.A., Paniccià R. (Oxford, Oxford University Press, 2000).

Shkolnikov V. M., McKee M., Chervyakov V. V., Kyrianov N. A., 'Is the link between alcohol and cardiovascular death among young Russian men attributable to misclassification of acute alcohol intoxication? Evidence from the city of Izhevsk', J Epidemiol Comm Health, 56 (2002), 171-174.

Siegrist J., 'Place, social exchange and health: proposed sociological framework', Soc Sci Med, 51 (2000), 1283-1293.

Silva I. D. S, Beral V., 'Socioeconomic differences in reproductive behaviour', in Social Inequalities and Cancer, eds. Kogevinas M., Pearce N., Susser M., Bofetta P., (Agency for Research on Cancer, 1997), pp. 285-308.

Simpura J., Levin B. (eds.), Demystifying Russian Drinking. Comparative Studies from the 1990s. Research Rep 85. (Helsinki, Gummerus Kirjapaino OY, 1997).

Skidelsy R., The Road from Serfdom: The Economic and Political Consequences of the End of Communism (New York, Allen Lane, 1995).

Sparen P., Vagero D., Shestov D. B., Plavinskaja S., Parfenova N., Hoptiar V., Paturot D., Galanti M. R., 'Long term mortality after severe starvation during the siege of Leningrad: prospective cohort study', BMJ, 328 (2004), 11.

Sullivan D. F., 'A single index of mortality and morbidity', HSMHA health report, 86 (1964), 347-54.

Treml V., 'Soviet and Russian statistics on alcohol consumption and abuse', in Premature Death in the New Independent States, Eds. Bobadilla, J.-L., Costello, C. and Mitchell, F. (Washington DC, National Academy Press, 1997), pp. 220-238.

Tulchinsky T. H., Varavikova E. A., 'Addressing the epidemiological transition in the former Soviet Union: strategies for health system and public health reform 
in Russia', Am J Publ Health, 86 (1996), 220-238.

Tunstall-Pedoe H., Kuulasmaa K., Mahonen M. et al., 'Contribution of trends in survival and coronary-event rates to changes in coronary heart disease mortality: 10-year results from 37 MONICA Project populations', Lancet, 353 (1999), 1547-57.

UNAIDS, 2002. Russian Federation. Epidemiological Facts Sheets on HIVIAIDS and sexually transmitted diseases. 2002 update. Available at http://www.who.int/emc-hiv/fact_sheets/pdfs/Russianfederation_EN.pdf.

United Nations, World population prospects as assessed in 1980 (New York, United Nations, 1981), p 3.

Vallin J., Meslé F., 'Trends in mortality in Europe since 1950: age-, sex- and causespecific mortality', in Trends in Mortality and Differential Mortality. (Strasbourg, Council of Europe, 2001), pp. 31-186.

Vallin J., Meslé F., 'Convergences and divergences in mortality. A new approach of health transition', Demographic Research, Special Collection 2, Article 2, 2004. Available at www.demograpghic-research.org

Vikhert A. M., Tsiplenkova V. G., Cherpachenko N. M., 'Alcoholic cardiomyopathy and sudden cardiac death', J Am Coll Cardiol, 8 (1986), 3A$11 \mathrm{~A}$.

Walberg P., McKee M., Shkolnikov V., Chenet L., Leon D., 'Economic change, crime and Russian mortality crisis: a regional analysis', BMJ, 317 (1998), 312318.

Watson P., 'Explaining rising mortality among men in Eastern Europe', Soc Sci Med, 41 (1995), 923-934.

White S., Russia goes dry (Cambridge, Cambridge University Press, 1995).

Willner S., Det svaga könet? Kön och vuxendödlighet i 1800-talets Sverige. [The Weaker sex? Gender and Adult Mortality in Nineteenth Century Sweden] Linköping Studies in Arts and Science, 203 (Linköping, 1999).

World Value Surveys, 2003. World Values Surveys and European Values Surveys 1981-1984, 1990-1993, and 1995-1997. Inter-University Consortium for Political and Social Research. ICPSR No 2790.

Wyon J. B., 'Deteriorating health in Russia - a place for community-based approaches (comment)', Am J Public Health, 86 (1996), 321-3.

Zohoori N., Henderson L., Gleiter K., Popkin B., Monitoring Health Conditions in the Russian Federation: The Russia Longitudinal Monitoring Survey 1992-2001. Report submitted to the U.S. Agency for International Development. (Carolina Population Center, University of North Carolina at Chapell Hill, North Carolina, 2002). 